\title{
Labour Supply Effects of Winning a Lottery*
}

\author{
Matteo Picchio, Sigrid Suetens and Jan C. van Ours
}

October 17, 2016

\begin{abstract}
Our paper investigates how winning a substantial lottery prize affects labour supply. Analysing data from Dutch State Lottery winners, we find that winning a lottery prize reduces labour earnings in the year of the winning, as well as in the years after the winning. This suggests that winning a lottery prize makes one work less hours. The effects are small but statistically significant. We do not find a significant effect of lottery prizes on the probability to be employed.
\end{abstract}

Income and wage affect the labour supply of individuals. Unless leisure is an inferior good, a change in wages has ambiguous effects on the preferred hours of work because the income effect and substitution effect work in opposite direction. A large part of the empirical literature on labour supply is focused on how a change in wages affects preferences for hours of work, disentangling the income effect from the substitution effect. However, the estimation of labour supply elasticities faces a number of problems (see Keane, 2011, for a discussion). The main problems are related to measurement errors in wages and non-labour income, endogeneity of wages and non-labour income arising from simultaneity or correlation with tastes for work, and unobservability of wages for non-workers. Labour supply changes due to changes in non-labour

\footnotetext{
${ }^{*}$ Corresponding author: Jan C. van Ours, Erasmus School of Economics, Erasmus University Rotterdam, Burg. Oudlaan 50, 3062 PA Rotterdam, The Netherlands; vanours@ese.eur.nl.

The authors thank the Dutch State Lottery and, in particular, Remco van Gastel and Arjan van 't Veer for their cooperation and for making the lottery data available for analysis, and Cyrille Fijnaut and Eric van Damme for establishing the contacts with the State Lottery. The authors also thank Statistics Netherlands (CBS) for making their restricted access micro-data available for analysis through a remote access facility. The authors are grateful to participants in the AIEL conference in Cagliari, Italy (September 2015) and anonymous reviewers for their helpful comments and suggestions.
} 
income may be informative about the income effect but such changes are often endogenous. Individuals with a strong preference for work and weak preferences for leisure may accumulate more assets and therefore have more non-labour income.

Our study presents an analysis of the effects of non-labour income on labour supply using information about lottery prize winners in the Netherlands. Data from lottery prize winners are useful to study income effects on labour supply because lottery prizes constitute a non-labour income shock. ${ }^{1}$ The psychology literature reports about a number of surveys of lottery winners. These suggest that lottery prizes tend to reduce labour supply for some individuals but not for the majority of prize winners. Kaplan (1987) analyses a survey of 576 US lottery winners of whom 139 won 1 million dollar or more. Although the majority of the prize winners did not change their work behaviour, of the million dollar winners, 1 in 4 stopped working. Not surprisingly, of the winners of less than 50,000 dollars none stopped working. This is in line with Arvey et al. (2004) who survey 117 US lottery winners finding that most winners continued working while only some quit their job or started working part-time. Similar conclusions are drawn in a series of studies based on a survey of 420 Swedish lottery winners. Hedenus (2012) concludes that the majority did not make any adjustment to their working life. Of the others some stopped working, took unpaid full-time leave several times, or reduced their working hours for a shorter or longer period. Furaker and Hedenus (2009) find that few prize winners stopped working, some of them took unpaid full-time leave, but for the vast majority this was less than a month. Some prize winners reduced their working hours, but on average less than 10 hours per week. Hedenus (2009) concludes that young winners living alone took periods of

\footnotetext{
${ }^{1}$ Alternatively, the issue of potential endogeneity of non-labour income may be addressed by focusing on labour supply effects of unanticipated inheritances. See for example Joulfaian and Wilhelm (1994) on earnings, and Goodstein (2008) and Brown et al. (2010) on the probability of retirement. In addition, changes in labour supply have also been linked to booms and busts in stock markets, assuming that at least part of these booms and busts are unforeseen. See for example, Hurd et al. (2009) on retirement.
} 
unpaid leave while female prize winners without children at home reduced their hours of work.

There are also a number of studies in the economic literature that use information about lottery prize winners to study labour supply effects. Imbens et al. (2001) estimate labour supply effects using data from the Megabucks lottery in Massachusetts, played in the 1980s, where major prizes are paid out in yearly instalments over twenty years. They contacted prize winners and asked them questions concerning labour earnings, and an authorization to release their Social Security earnings. They find significant income effects and report a marginal propensity to earn out of unearned income of about -0.11 , indicating that an increase in non-labour income of $\$ 100,000$ would reduce earnings by $\$ 11,000$. Kuhn et al. (2011) survey winners from the Dutch Postcode Lottery to measure labour market participation and do not find significant effects on earnings. This result is not surprising given that the size of the prize is either $€ 12,500$ or a BMW-car, so likely not sufficiently high to induce changes in labour market behaviour. Jacob and Ludwig (2012) study the effects of a housing voucher lottery on labour supply of low-income families in Chicago in the late 1990s. Given that supply of housing vouchers far exceeded demand, a lottery was installed to randomly allocate the vouchers. Families who received the voucher experienced an increase in permanent income, but also a reduction in their wages through an increase in their marginal tax rate. The authors compare employment and earnings in families who applied and were not offered a voucher with families who applied and were offered a voucher. They find that the housing vouchers reduce both the employment and earnings, and calibrate an income elasticity of -0.09 . They also report that the housing vouchers reduced the employment rate of women by $6 \%$, whereas there was no effect on employment of men. Most closely related to our study is Cesarini et al. (2015), who study the effect of lottery prizes on individual and household labour supply in a panel data set of Swedish lottery 
players. They find significant responses at the intensive and extensive margin. To illustrate, they find that winning a lottery prize immediately and permanently reduced earnings for more than 10 years with an estimated lifetime marginal propensity to earn out of unearned income of about -0.11 . They do not find significant differences according to age or gender.

In our paper, we use panel data from winners of lottery prizes in the Dutch State Lottery and match these with data on individual-level labour supply and with household-level administrative data. Studying the Dutch labour market is particularly interesting. Whereas in many countries adjusting weekly working hours is not easy, in the Netherlands it is usually no problem for workers to adjust their working hours. Part-time employment has increased a lot during the past decades. ${ }^{2}$ This increase has been accompanied by changes in collective agreements between unions and employers and changes in labour law that made part-time jobs more attractive. Since the early 1990 s protective provisions for part-time workers were included in collective agreements (Roeters and Craig, 2014). From 1990 to 1996 the percentage of firms with a part-time clause in the collective agreement increased from 23 to 70 percent (Visser et al., 2004). In the past, two labour laws have been important. The first one is the Prohibition of Discrimination by Working Hours Act, which came into effect on 1 November 1996. This law forbids employers to discriminate between workers on the basis of a difference in working hours. The second law is the Adjustment of Working Hours Act, which came into force June 2000. Under this law a request of a worker to modify his or her working hours must be granted by the employer, unless it would seriously harm business. Currently, the majority of working women have a part-time job and high levels of job satisfaction (Booth and van Ours, 2013).

We track lottery players and winners over a number of years and study their labour supply

\footnotetext{
${ }^{2}$ In the Netherlands, in 2013 the fraction of part-time workers on total employment (15-64 years) was 26.2\% for men and $77.0 \%$ for women. In the European Union (15 countries), the same statistics were $9.7 \%$ for men and $38.2 \%$ for women (Eurostat, Labour Force Survey, http://ec.europa.eu/eurostat/web/lfs/data/database).
} 
responses focusing on employment and earnings. Labour market information from lottery prize winners is an ideal source for estimating the effect of income shocks on labour supply. For one, they come from a random draw and are thus as close as one can get to an unforeseen, random shock in permanent income. Moreover, lottery prizes are unearned and potentially substantial in size. Once a person enters a lottery, winning the lottery is a random event, exogenous to labour supply. However, participation in a lottery is not a random event. Individuals with a strong preference for leisure may be more likely to participate in the lottery. We return to this issue below when we discuss our econometric model.

Our main finding is that winning a substantial lottery prize has a significant effect on the intensive margin of labour supply. The lottery prize effects last for several years which suggests that the unexpected non-labour income is used for intertemporal smoothing of labour supply. Our parameter estimates indicate that, overall, a large lottery prize of $€ 500,000$ leads to a drop in earnings of about $€ 6,000$ in the year of the winning as well as after one year, of $€ 8,000$ after two years, and of almost $€ 9,000$ after three years. Adding up the reduction in earnings over the first 3 years, which is about $€ 23,000$, results in a marginal propensity to earn out of unearned income of -0.046 . If we remove lottery prizes above $€ 500,000$ from the sample, we only find an instantaneous effect in the year the prize was received. For that year we find a marginal propensity to earn out of unearned income of -0.056 . Finally, regarding the extensive margin of labour supply, we find that lottery prizes have a small negative effect on employment. However, this effect is imprecisely estimated and not significantly different from zero.

How do our results compare to estimates in other studies? It is not easy to compare our results with Imbens et al. (2001), who find a marginal propensity to earn out of unearned income of -0.11 . The reason is that in the lottery they study, prizes are paid out in yearly 
instalments over a period of 20 years whereas in the lottery we study, there is a one-time payment. The comparison with Cesarini et al. (2015) is easier. They find a 3-year total marginal propensity to earn out of unearned income of -0.033 which is not very different from the estimate we obtain.

Our contribution to the labour supply literature is twofold. First, we add to the small literature that exploits lottery data to analyse how exogenous shocks to non-labour income affect earnings and employment. Second, as indicated before, we analyse labour supply behaviour in a labour market in which workers can easily adjust their labour supply at the intensive margin.

Our paper is set up as follows. In Section 1 we describe the different data sets and provide descriptive statistics. Section 2 focuses on the econometric model and estimation procedures. In Section 3 we present the estimation results. Section 4 concludes.

\section{The data}

Our empirical analysis is based on data sets from two sources. The first source of data is the State Lottery in The Netherlands (www.staatsloterij.nl). The State Lottery data set contains information of the State Lottery subscribers in the time window 2005-2008. The second data source is Statistics Netherlands. From Statistics Netherlands we use two data sets also spanning the period from 2005 until 2008: (i) the Municipal Personal Records Database (GBA), containing demographic, family, and residence information of all the people registered in a Dutch municipality; (ii) the Social Statistical Database of Jobs (SSB Jobs), containing information on salaried jobs.

In order to guarantee anonymity and confidentiality, the lottery data set and the GBA data set were merged by Statistics Netherlands on the basis of the day of birth and address of indi- 
viduals. Specifically, Statistics Netherlands was provided with a sample of lottery players with information on their day of birth, address, lottery prizes, and expenditures in lottery tickets by year. Statistics Netherlands matched this sample with the GBA data set, and then gave us permission to work with the linked data set on a terminal located in the Department of Economics of Tilburg University and connected via internet to their servers through a secure connection. In what follows, we describe more in detail the data sets used in this study and the steps taken to come to the final sample exploited in the main analysis.

\subsection{The lottery data}

The Dutch State Lottery sells lottery tickets and organizes monthly draws of a number of winning tickets. Additional draws (maximum three) are organized at special occasions throughout the year, for example, at the end of the year ("Eindejaarstrekking") and at Queen's day ("Koninginnedag"). In the period of study, there were 55 draws in total (13 in 2005, 14 in 2006, 2007, and 2008). Each ticket consists of a combination of two letters and six numbers. Lottery players do not choose the full combination themselves when they buy a ticket. Instead, they can only choose the last one or two numbers (see also footnote 5). Whether an individual wins a prize and the amount of the prize depend on the degree of correspondence between the letters and numbers on the individual's ticket and those on the tickets drawn. The prize amount also depends on the type of ticket: people can choose between "full" tickets and "partial" tickets. A full ticket costs $€ 15$ and pays the full amount if it is a winning ticket. A partial ticket costs $€ 3$ and pays one fifth of the full prize if it is a winning ticket. The full prizes in each draw vary from $€ 5$ to $€ 1$ million. In each draw, the main prize of $€ 1$ million (or one fifth of it) is guaranteed for one of the tickets. Draws are repeated until someone wins the main prize. 
In each draw, also 10 prizes of $€ 100,000,10$ prizes of $€ 25,000$, and 20 prizes of $€ 10,000$ are allocated to winning tickets. Furthermore, each draw has a number of smaller prizes, ranging from $€ 5$ to $€ 1,000$, which are allocated to tickets in which only part of the numbers overlap with the ones on the winning tickets. For example, in each draw a winning "end number" is drawn. Tickets with codes ending with this number pay a $€ 5$ prize. Finally, for an additional amount of money (about $15 \%$ extra), players can also play for the so-called "Jackpot". ${ }^{3}$ The Jackpot is an additional large prize of at least $€ 7.5$ million, of which the amount is decided by the State Lottery. The Jackpot is not guaranteed in each draw and, if there is no ticket that wins the Jackpot in a certain draw, the full amount is transferred to the next one. ${ }^{4}$

About half of the individuals who bet in the State Lottery in The Netherlands do so through a subscription. ${ }^{5}$ Each month an amount of money is automatically transferred from their bank account to the State Lottery's bank account. For each subscriber, we have information about the amount of prizes they won in each draw in the period 2005-2008 with the ticket(s) bought through the subscription, and the amount they spent on the subscription in each of these years. To be more precise, the information we have about the amount spent by the players consists of expenditures by draw that the State Lottery has estimated. It consists of the expected (by the State Lottery) yearly amount the player would spend on lottery tickets if he/she would continue

\footnotetext{
${ }^{3}$ Unfortunately, we do not have detailed information about which players pay the extra $15 \%$ to play for the Jackpot.

${ }^{4}$ Table A.1 in Appendix A provides details about the current prize structure. The prize structure has been relatively constant over time since 2005 when a major change occurred: the Jackpot was introduced and the relative number of large prizes was reduced. Whether or not the Jackpot is paid depends on a separate lottery which consists of a random draw of one ball out of 6 blue balls and 1 orange ball. If the orange ball is drawn, the Jackpot is paid to one of the lottery players who paid the additional amount of money of $15 \%$. If a blue ball is drawn, no Jackpot is paid and the Jackpot rolls over to the next draw and is now $€ 15$ million. If a blue ball is drawn this ball is removed from the next lottery which then consists of 5 blue balls and 1 orange ball. If then again a blue ball is drawn, the Jackpot again rolls over and the draw is from 4 blue balls and 1 orange ball. The draw after one with an orange ball restarts with 6 blue balls and 1 orange ball.

${ }^{5}$ Subscribers only have the option to choose the last number of the combination of two letters and six numbers on a ticket. They have three options: (1) use the same combination in every draw (of which only the last number is chosen by the subscriber), (2) use a randomly drawn combination in every draw, or (3) use the same, self-chosen last number in every draw combined with a randomly drawn combination of other numbers and letters.
} 
his/her subscription for one additional year at the moment of the draw. When a player decides to modify the expenditures in tickets, the State Lottery updates the expectations on the amount spent by that player. Because the labour market data are only available at a yearly basis, we calculated the expenditures of the players on a yearly basis simply by taking the average of the estimated (yearly) expenditures across all draws in a year.

The data set consists of 1,975,665 individuals who subscribed for at least one draw of the State Lottery between 2005 and 2008. In total, 1,913,901 individuals won a strictly positive (but possibly very small) prize. Out of these, we draw a sample of individuals that consists of two sub-samples. The first sub-sample includes all subscribed individuals who won more than $€ 1,000$ in total in the sample period, which amounts to 7,663 individuals in total. The second sub-sample consists of a $1 \%$ sample of the remaining subscribers, in total 22,070 individuals.

Our total sample of State Lottery winners, before being matched with the administrative data sets of Statistics Netherlands, thus consisted of 29,733 individuals. For these individuals, we know how much they spent on lottery tickets in each year and how much prize money they win in each year, both through their subscription.

\subsection{The demographic and labour market data}

The data on demographics are in the GBA database and the data on salaried jobs are in the SSB Jobs database. Both databases contain an individual identifier, which allows the data from both sources to be linked. The GBA database includes the date of birth and the address of residence of the individuals, as well as identifiers of other members of the individual's household. The latter information makes it possible to study the impact of lottery prizes at the family level as well, next to the effects at the individual level. The SSB Jobs database contains information at 
the level of each single job of individuals employed by an employer located in the Netherlands.

In a first step, Statistics Netherlands merged our lottery data set with the GBA database on the basis of the date of birth and the address of residence of the lottery players. Statistics Netherlands was able to match about $62 \%$ of the individuals of our State Lottery data set to the GBA database. This means that $38 \%$ of the players in our sample could not be matched. For $22 \%$ of the players in our sample no birth date was available. The remaining $16 \%$ was lost because of mistakes in the date of birth and postal addresses, for example, because players had moved between the point in time their data was entered in the lottery data set and the (more recent) time their data was adjusted in the GBA database. We have no information to determine which fraction of the loss was due to actual mistakes in the coding or due to players moving.

In a second step, we linked the merged data set that resulted from the first step with the SSB Jobs database. Roughly all individuals who are in the SSB Jobs database can be linked to the GBA database. Exceptions are individuals who work in the Netherlands and live outside the Netherlands, but this is a negligible fraction of the labour market population, and irrelevant for the sample of State Lottery players. In order to calculate the annual labour earnings we summed up all earnings on a yearly basis across the different jobs held by each employee during the year. After this second step, we were left with a sample of 60,601 lottery prize observations covering 18,390 individuals, for whom we have information about the yearly gross salaries from 2005 until 2008.

In a third step, we restricted the sample to the working-age population, namely to those individuals who are above 17 and below 65 years of age at the time of the lottery win. In addition, we removed the observations covering winners of the Jackpot (two observations with prizes equal to $€ 15$ million and $€ 22.5$ million). Also, since we focus on "standard" individuals, 
we removed observations related to individuals who are not single, nor living in a couple. These observations come, for example, from young individuals who live with their parents, or from individuals who live in a large family, which is very uncommon. Finally, in order to avoid biases due to observations with uncommon earnings or uncommon time variation in earnings, we also removed those observations lying in the first or last percentiles of the earnings or change in earnings distribution. This left us with 45,326 lottery prize observations covering 13,391 individuals.

In our analysis, we focus on those individuals who are at work in a salaried job in the year of the prize win. The reason is that we expect a decrease in earnings or employment caused by winning a high lottery prize to occur only for those individuals who have a job in the first place. Our main analysis is based on 35,523 observations, corresponding to 10,871 individuals. Table 1 gives an overview of the distribution of yearly prizes (a) in the original State Lottery data set, (b) after merging of the lottery, demographic and labour market data, and (c) in the final sample of players who have a job in the year of winning a lottery prize. As shown in this table, the distribution of the prizes is very similar in the three samples.

\subsection{Summary statistics}

Our aim is to study the effect of lottery wins on yearly labour earnings and employment in the year of the lottery win and in subsequent years. Our observed time window covers four years, from 2005 until 2008. Our main analysis will consist of estimating the impact of lottery prize money on labour earnings or employment status in the year of the lottery win and one, two and three calendar years later. The more we look ahead, the smaller the number of observations. We will run regressions at the level of individual players and at the level of households. 
Table 1: Distributions of prizes

\begin{tabular}{|c|c|c|c|c|c|}
\hline \multicolumn{6}{|l|}{ Prizes } \\
\hline \multicolumn{6}{|c|}{ (a) Original State Lottery data set } \\
\hline$[0, € 10,000]$ & 29,365 & 29,435 & 29,441 & 29,473 & 117,714 \\
\hline$(€ 10,000 ; € 100,000]$ & 262 & 265 & 262 & 229 & 1,018 \\
\hline$>€ 100,000$ & 106 & 33 & 30 & 31 & 200 \\
\hline Total & 29,733 & 29,733 & 29,733 & 29,733 & 118,932 \\
\hline \multicolumn{6}{|c|}{ (b) After merging with demographic and labour market data } \\
\hline$[0, € 10,000]$ & 18,158 & 18,205 & 18,208 & 18,236 & 72,807 \\
\hline$(10,000 ; € 100,000]$ & 163 & 161 & 164 & 135 & 623 \\
\hline$>€ 100,000$ & 69 & 24 & 17 & 19 & 129 \\
\hline Total & 18,390 & 18,390 & 18,390 & 18,390 & 73,560 \\
\hline \multicolumn{6}{|l|}{ (c) Final sample } \\
\hline$[0, € 10,000]$ & 8,953 & 8,566 & 8,727 & 8,836 & 35,082 \\
\hline$(€ 10,000 ; € 100,000]$ & 100 & 93 & 95 & 72 & 360 \\
\hline$>€ 100,000$ & 46 & 16 & 7 & 12 & 81 \\
\hline close to $€ 100,000$ & 39 & 11 & 6 & 6 & 62 \\
\hline close to $€ 200,000$ & 2 & 2 & 0 & 1 & 5 \\
\hline above $€ 500,000$ & 5 & 3 & 1 & 5 & 14 \\
\hline Total & 9,099 & 8,675 & 8,829 & 8,920 & 35,523 \\
\hline
\end{tabular}

Table 2 reports the number of observations and the summary statistics of the variables used in the empirical analysis in the individual-level regressions. The first column displays summary statistics of the sample we used to study the impact of yearly lottery prizes on current yearly earnings $(T=0)$. This is the largest sample, as it covers all four years. The subsequent three columns report descriptive statistics for later years $(T=1,2,3)$. In the extreme case in which we study the effect three years ahead, we are left with a cross-section: individuals winning prizes in 2005 whose earnings are observed in 2008. The explanatory variables can be split into time-constant and time-varying covariates. Gender and nationality (whether Dutch or not) are the time-constant regressors. The time-varying covariates (age, the number of children in the household, and household status measured by a binary variable that indicates whether the individual is single or not) are measured at time $t$ of lottery participation, with $t=2005, \ldots, 2008$. The average yearly gross earnings in the full sample are $€ 37,093$. In a year, lottery subscribers spend on average $€ 224$ and win $€ 113$. The average age of players is 
45 years, $32 \%$ of the players is female, and $21 \%$ is single (the remaining $79 \%$ lives in a couple). People with Dutch nationality represent almost $97 \%$ of the sample and, on average, there is one child in the lottery players' household. Compared to the Dutch population in 2005 (18 years and older), our sample has about the same average labour earnings per household, the same number of children per household, and the same age. Our sample has a substantial lower share of females, non-Dutch, and singles than the Dutch population had in 2005 (see Table A.2 in Appendix B).

Table 2: Summary statistics

\begin{tabular}{|c|c|c|c|c|c|c|c|c|}
\hline & \multicolumn{2}{|c|}{$T=0$} & \multicolumn{2}{|c|}{$T=1$} & \multicolumn{2}{|c|}{$T=2$} & \multicolumn{2}{|c|}{$T=3$} \\
\hline & Mean & St. dev. & Mean & St. dev. & Mean & St. dev. & Mean & St. dev. \\
\hline Labour earnings in $t+T(€)$ & 37,093 & 21,779 & 37,814 & 26,791 & 37,514 & 27,059 & 36,939 & 27,017 \\
\hline Lottery wins in $t(€)$ & 113 & 2,506 & 109 & 2,277 & 107 & 2,623 & 101 & 2,848 \\
\hline Lottery expenditures in $t(€)$ & 224 & 166 & 221 & 167 & 221 & 163 & 218 & 156 \\
\hline Female & 0.322 & 0.467 & 0.323 & 0.468 & 0.318 & 0.466 & 0.315 & 0.465 \\
\hline Age in $t$ (years) & 45.3 & 9.5 & 44.7 & 9.6 & 44.5 & 9.6 & 44.5 & 9.6 \\
\hline \# children in $t$ & 0.945 & 1.052 & 0.952 & 1.054 & 0.954 & 1.058 & 0.957 & 1.062 \\
\hline Dutch & 0.969 & 0.173 & 0.968 & 0.175 & 0.969 & 0.173 & 0.970 & 0.170 \\
\hline Single in $t$ & 0.203 & 0.402 & 0.201 & 0.401 & 0.198 & 0.398 & 0.198 & 0.398 \\
\hline 2005 & 0.263 & 0.440 & \multicolumn{2}{|c|}{ - } & \multicolumn{2}{|c|}{ - } & \multicolumn{2}{|c|}{ - } \\
\hline 2006 & 0.246 & 0.430 & 0.332 & 0.471 & \multicolumn{2}{|c|}{ - } & \multicolumn{2}{|c|}{ - } \\
\hline 2007 & 0.245 & 0.430 & 0.331 & 0.470 & 0.498 & 0.500 & \multicolumn{2}{|c|}{ - } \\
\hline 2008 & 0.246 & 0.431 & 0.337 & 0.473 & 0.502 & 0.500 & 1.000 & 0.000 \\
\hline Observations & \multicolumn{2}{|c|}{35,523} & \multicolumn{2}{|c|}{28,062} & \multicolumn{2}{|c|}{18,499} & \multicolumn{2}{|c|}{9,182} \\
\hline
\end{tabular}

Notes: Labour earnings are gross earnings. "\# children” stands for the number of children in the household. Sample weights are used to take into account that individuals winning less than $€ 1,000$ are a $1 \%$ random draw from the population of small-prize lottery winners. The time varying covariates are measured at the time $t$ of lottery participation, with $t=2005, \ldots, 2008$. All the monetary values are in real terms (CPI in $2005=100)$.

Table 3 reports mean labour earnings and employment rates of individuals in the three categories of lottery prizes: small (smaller than $€ 10,000$ ), medium (between $€ 10,000$ and $€ 100,000$ ), and large (more than $€ 100,000$ ). This table provides a raw indication of the presence of a relationship between lottery prizes and labour supply, unconditional on individual characteristics. For example, two years after lottery participation $(T=2)$, large-prize winners earn about $€ 1,750$ less than small-prize winners. Three years later, large-prize winners earn about $€ 106$ less than small-prize winners. If we compare earnings of large-prize winners to those of medium-prize winners, we see that the former earn up to $€ 6,900$ less than the latter. 
Moreover, the employment rate of large-prize winners is about 5 percentage points lower than the one of small-prize winners three years after lottery participation. If we look at $T=0$, we see that large-prize winners earn almost $€ 1,800$ less than small-prize winners, suggesting that they work less in the year of winning the large prize. These statistics indicate that lottery prizes might induce some labour supply response, either immediately or after a while.

There is also quite some variation in the data that seems to be unrelated to prize winning. For example, average labour earnings in each of the categories are higher in $T=1$ than in $T=0$. Furthermore, the unconditional relations might be biased due to the presence of omitted variables, especially ticket expenditures. The ticket expenditures might indeed be correlated to both earnings at the time of winning - richer players might buy more (or less) tickets - and the probability of winning small and medium prizes. In the empirical analysis, we will control for ticket expenditures to solve for the omitted variables problem, as well as for a set of individual and household characteristics potentially affecting labour earnings and employment.

Table 3: Labour supply in $T$ by size of lottery prize (standard deviation in parenthesis)

\begin{tabular}{lcccc}
\hline \multirow{2}{*}{ Prizes } & $T=0$ & $T=1$ & $T=2$ & $T=3$ \\
\hline \multirow{2}{*}{$€ 10,000]$} & $37,093(21,779)$ & $37,813(26,789)$ & $37,513(27,058)$ & $36,938(27,016)$ \\
$(€ 10,000, € 100,000]$ & $39,876(25,695)$ & $44,248(35,487)$ & $42,713(32,939)$ & $39,609(26,786)$ \\
$>€ 100,000$ & $35,305(18,896)$ & $38,158(33,236)$ & $35,755(30,429)$ & $36,832(30,387)$ \\
\hline & \multicolumn{4}{c}{ Employment rate } \\
{$[0, € 10,000]$} & $1.000(0.000)$ & $0.966(0.180)$ & $0.945(0.229)$ & $0.919(0.273)$ \\
$(€ 10,000, € 100,000]$ & $1.000(0.000)$ & $0.977(0.149)$ & $0.966(0.181)$ & $0.920(0.273)$ \\
$>€ 100,000$ & $1.000(0.000)$ & $0.961(0.196)$ & $0.940(0.240)$ & $0.870(0.341)$ \\
\hline Observations & 35,523 & 28,062 & 18,499 & 9,182 \\
\hline
\end{tabular}

Notes: Standard deviations are in parentheses. Labour earnings are yearly gross labour earnings. Sample weights are used to take into account that individuals winning less than $€ 1,000$ are a $1 \%$ random draw from the population of small-prize lottery winners. Since we focus on individuals who are employed in the year they win the lottery prize, the employment rate at $T=0$ is equal to 1 by construction. All the monetary values are in real terms (CPI in $2005=100$ ). 


\section{Econometrics}

\subsection{Model}

We are interested in quantifying the impact of income shocks at the extensive margin and the intensive margin of labour supply. In order to quantify the impact at the intensive margin of labour supply, we study the effect of winning lottery prizes on yearly salaried earnings of individuals/households. At the extensive margin of labour supply, we focus on whether or not the earnings of individuals become zero (i.e. the individual disappears from the SSB Jobs database) in the years after the lottery participation.

Under the assumption that leisure time is not an inferior good, we expect a negative impact of winning the lottery on labour supply only for (households with) individuals who are employed at the time of winning, and not so for individuals who are not employed at the time of winning. This is the reason why in our benchmark model, we focus on (households with) individuals who are employed at the time of winning a prize. We denote by $t$ the year in which individuals or households participate in the lottery, with $t=2005, \ldots, 2008$. Furthermore, we denote by $p_{i t}$ the lottery prize of individual or household $i$ in year $t$. Finally, we denote by $y_{i t+T}$ the outcome variable, where $T$ indicates how many years after the lottery win the outcome variable is measured. When we study the impact at the intensive margin, $y_{i t+T}$ will indicate the yearly salaried gross earnings $T$ years after lottery participation, with $T=0,1,2,3$. When we look at the effect at the extensive margin, $y_{i t+T}$ will be a dummy indicator equal to one if individual $i$ was an employee in year $t+T$, and zero otherwise (we do not include an analysis at the household level of the effects at the extensive margin). At the extensive margin, $T$ does not take value 0 , since in the year of lottery participation everybody is in salaried employment 
by sample construction. Our main equation for labour market outcome $y_{i t+T}$ is:

$$
y_{i t+T}=\mathbf{x}_{i t}^{\prime} \boldsymbol{\beta}_{T}+p_{i t} \delta_{T}+u_{i t+T}
$$

where $u_{i t+T}$ is the error term, $\mathbf{x}_{i t}$ is a set of predetermined regressors measured at the time $t$ of the lottery participation, and $\delta_{T}$ is the linear effect of the lottery prize on the labour market outcome $T$ years ahead. Ordinary Least Squares (OLS) estimation of Eq. (1) returns unbiased estimates of $\boldsymbol{\delta}_{T}$ if the lottery win is uncorrelated to the error term conditional on $\mathbf{x}_{i t} .{ }^{6}$ This is the case if there are no other relevant variables correlated with the labour market outcome variable and lottery prizes. Among the set of control variables we have ticket expenditures, age, squared age, number of children in the household, nationality, gender, household status (i.e. whether single or living in a couple), year dummies, and the constant.

Importantly, the year dummies capture the time fixed effects. Each year, the Dutch State Lottery slightly changes the prize structure, influencing thereby the realization of the prize variable. Moreover, gross salaries might also vary each year due to, for instance, the business cycle, changes in labour market conditions, new contractual agreements between unions and firms, etc. Not introducing year fixed effects among the regressors may lead to spurious correlation between yearly lottery prizes and yearly gross salaries.

As indicated in the introduction, winning the lottery is a random event for lottery participants. However, participating in the lottery and the amount of money individuals spend on buying lottery tickets might be non-random events. Therefore, controlling for ticket expenditures is very important. The probability of winning prizes (especially small prizes) can be

\footnotetext{
${ }^{6}$ It may be that the presence of a big "Jackpot" might convince some people to subscribe to the lottery. However, even if this is the case, winning the lottery is not correlated to the error term in our regressions.
} 
affected by the number of purchased lottery tickets and, hence, by how much is spent on lottery tickets. Ticket expenditures can in turn be (positively) correlated with earnings. So, if we do not control for ticket expenditures and if there is positive correlation between earnings (or the probability of being at work) and tickets expenditures, OLS will overestimate the impact of lottery prizes on employment earnings (employment probability). Luckily, we have information on the players' yearly expenditures on lottery tickets and we can include this variable in the model specification.

In summary, our identification strategy relies on the prize variation between lottery subscribers, conditional on ticket expenditures and time fixed effects, and other individual (household) characteristics. Henceforth, it is based on the comparison of yearly gross earnings of subscribers who were randomly assigned yearly lottery prizes, conditional on ticket expenditures, time fixed effects, and individual (household) characteristics.

We assume that the variation of the lottery prizes is exogenous in our data. There may be instances, however, in which prize variation is not exogenous. First, the data only cover expenditures and prizes won by players who have a subscription to play, and not over-the-counter expenditures or prizes won through tickets sold over-the-counter. For example, think of subscribed players who also buy lottery tickets over-the-counter, and win a large prize with an over-the-counter ticket. If they adjust their subscription in response to this winning, then variation in prizes is not exogenous. Second, the data we have are yearly estimates obtained from monthly subscription expenditures. If it happens to be the case that players who participate only in certain months of the year, and then terminate their subscription, are different from players who participate throughout the whole year, then prize variation is not exogenous either. In order to shed more light on the robustness of the random assignment of lottery prizes, we 
regressed, in the spirit of Imbens et al. (2001), the yearly lottery prizes at time $t$ on the yearly ticket expenditures at time $t$, the time fixed effects, and the individual characteristics at time $t$ (gender, age, age squared, number of children in the household, nationality, and household status). If the random assignment assumption holds, the individual characteristics should not be able to predict the lottery prizes. This is exactly what we find: testing for the joint and the individual significance of the coefficients of the individual characteristics does not lead to the rejection of the null hypothesis of a zero effect (see Appendix E, Table A.5). This provides support for the random assignments of the lottery prizes, conditional on ticket expenditures and year fixed effects. ${ }^{7}$

The individual characteristics are measured in the same year as the lottery prizes. One may therefore wonder whether they are not predetermined but rather influenced by the lottery win in the same year. Among our set of individual characteristics only the number of children and household status are time-variant (along with age but this varies at an exogenous rate). Possibly their realization at time $t$ could be affected by the lottery win at time $t$. In order to check whether the lottery prizes could change the household status and the number of children, we checked whether the change in the household status and the change in the number of children between year $t-1$ and year $t$ correlate to the lottery prize at time $t$, conditional on all the control variables used in the baseline model. We cannot reject the null hypothesis of zero correlation between the change in the household status and in the number of children. The $p$-values are equal to $0.780,0.405$, and 0.744 for $T=0, T=1$, and $T=2$, respectively. We cannot compute this test for $T=3$ because to construct the change in the household status and in the number of children we lose one time period.

\footnotetext{
${ }^{7}$ Notice that this exercise is based on individual-level data. A similar exercise done using household data gives the same qualitative results. These results are available upon request.
} 


\subsection{Correction for finite-sample bias}

Our lottery prize variable is heavily skewed, with a large mass of small prizes and few large prizes. As pointed out by Cesarini et al. (2016), with heavily skewed data, the asymptotic distribution of a test statistic based on analytic standard errors could be poorly approximated and the related inference suffers of finite-sample bias, although the sample size satisfies conventional rules of thumb for being defined as large. In order to check whether inference based on analytical standard errors might be affected by a finite-sample bias, we follow Cesarini et al. (2016) and recover the sampling distribution of the test statistic when the null hypothesis is true using a permutation procedure (re-sampling without replacement) on prizes, conditional on the other regressors. ${ }^{8}$ In this subsection, we report the results from this exercise applied to our main individual-level regressions of which the results are reported in the upper part of Table $4 .{ }^{9}$

Similarly to Cesarini et al. (2016), we run the following algorithm 1,000 times:

1. Re-sample without replacement the lottery prizes and attach them to each observation.

2. Re-estimate Eq. (1) with the randomly permuted lottery prizes.

3. Save the estimated coefficient of lottery prize along with the analytical $p$-values, computed from standard errors robust to heteroskedasticity and within-individual correlation.

At this point we have the sampling distribution of the effect of lottery prizes on the outcome variable (either labour earnings or employment status) and of the analytical $p$-values under the

\footnotetext{
${ }^{8}$ Permutation tests (or randomization tests) were introduced by Fisher (1935). See e.g. Box and Andersen (1955) and Welch (1990), for further details on permutation tests.

${ }^{9}$ The same conclusion is made using household data instead, or using data referring to subgroups (as in Section 3.3). Results of these analyses are available upon request. In what follows, for all of our analyses, we report permutation-based $p$-values.
} 
Figure 1: Distributions of $p$-values
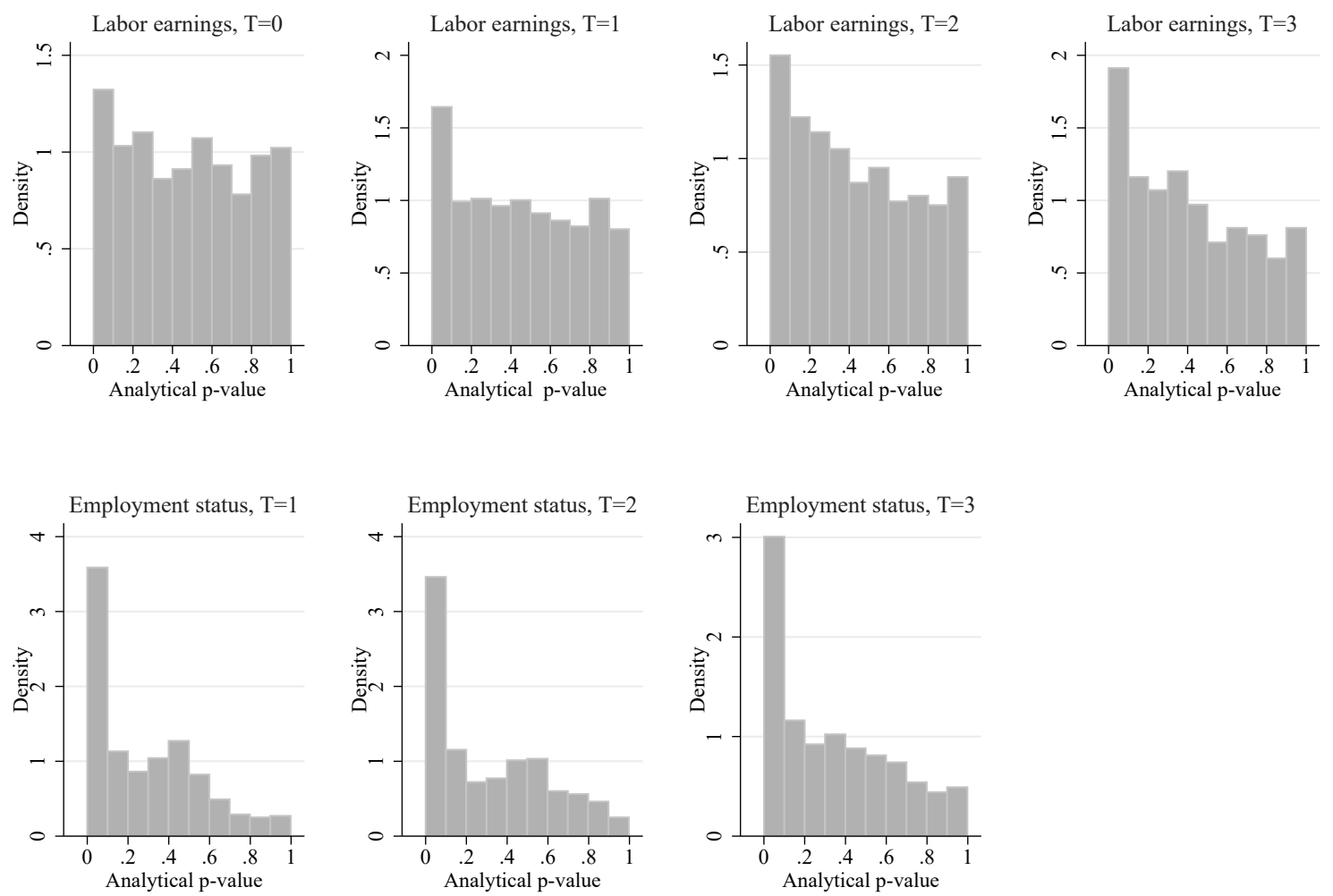

Notes: The histograms report the simulated distributions of analytical $p$-values under the null hypothesis that there is no effect of lottery prizes on the relevant dependent variable (labour earnings or employment status). 
null hypothesis of nil effect of lottery prizes on the dependent variable. If the analytical $p$ values are unbiased, the 1,000 realizations should be uniformly distributed on the unit interval. Figure 1 reports the simulated distributions of the analytical $p$-values under the null hypothesis that lottery prizes do not affect the dependent variables in the different benchmark models. It graphically shows that we have a problem of finite-sample bias when making inference with usual analytical standard errors.

On the basis of the simulated distribution of the estimated effect of lottery prizes under the null hypothesis, we can compute permutation-based $p$-values which are robust to finite-sample biases. They equal the probability that the actual estimated coefficient would be at least as extreme as we observe if the null hypothesis is true. Hence, the two-sided permutation-based $p$-values are equal to $2 \cdot \min (1-\tau, \tau)$, where $\tau$ is the percentile ranking of the actual estimated coefficient in the simulated distribution of coefficients. In what follows, inference will rely on permutation-based $p$-values, although we will also report the analytical standard errors.

\section{Estimation results}

\subsection{Main results}

Table 4 presents the estimation results from our regressions. The upper part of the table reports results from individual-level regressions and the lower part of the table reports results from household-level regressions. ${ }^{10}$ The table shows that overall the effect of winning a lottery prize on labour earnings is significantly negative. Focusing on the results from individual-level regressions, in the year of the winning, the magnitude of the effect is -0.116 , which implies

\footnotetext{
${ }^{10}$ Section $\mathrm{C}$ in the Appendix gives an overview of all parameter estimates, including the control variables.
} 
that if an individual wins $€ 100,000$, earnings go down by an amount of $€ 1,160$. In the next year, the effect remains the same. Moving on to two and three years ahead, the effect becomes larger in size. This suggests that some individuals may need some time to react to winning a large lottery prize. ${ }^{11}$ To illustrate, in the second year after winning $(T=2)$ earnings go down by an amount of $€ 1,640$ if the prize equals $€ 100,000$. Three years later ( $T=3$ ) this is $€ 1,770$. The impact of a large lottery prize on earnings thus seems to persist over time. ${ }^{12}$ Estimations based on data at the household level yield qualitatively similar results, with effect magnitudes that are overall somewhat larger, except in $T=3$.

Table 4: Lottery prize effects

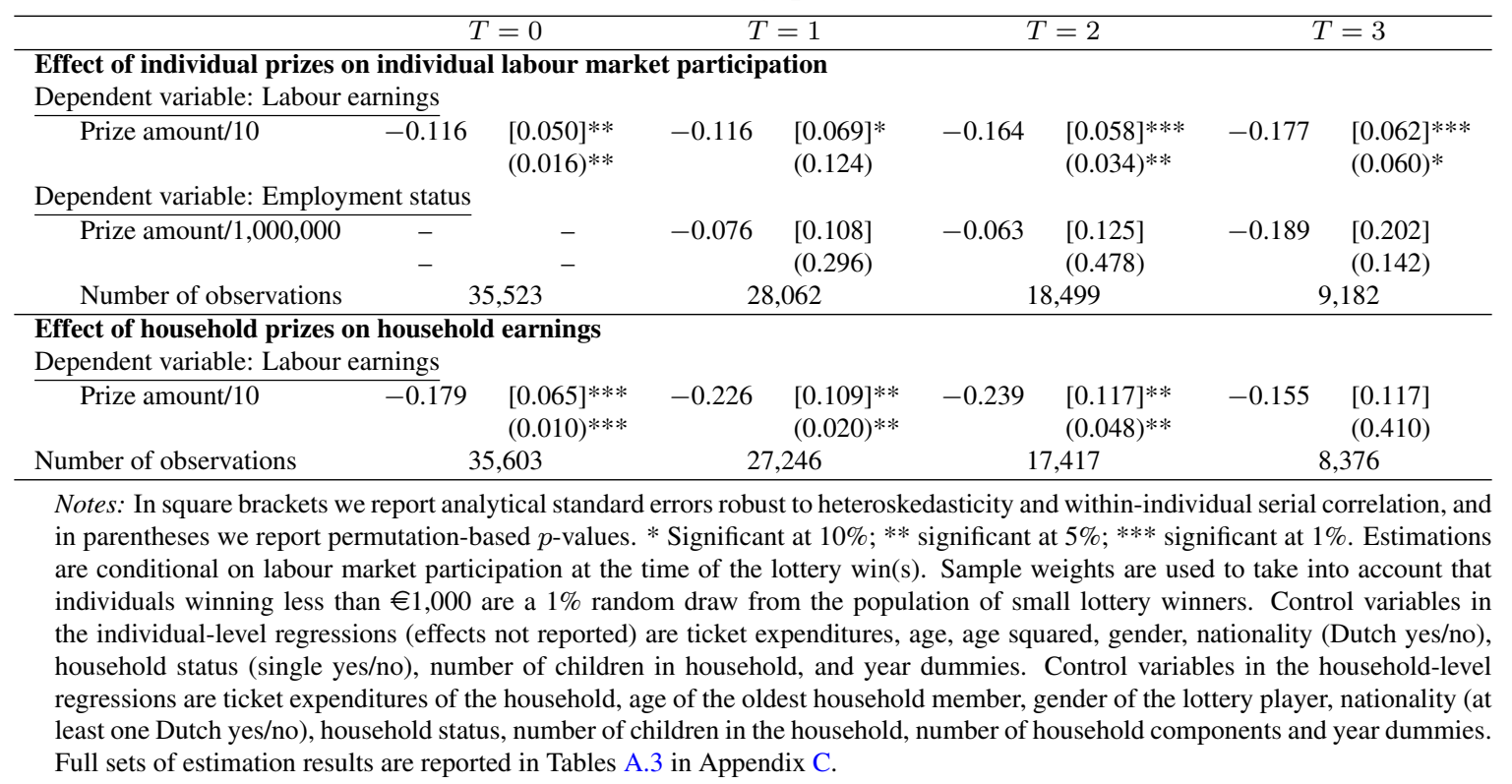

The middle part of Table 4 shows the effect of winning a substantial lottery prize on the probability to be employed. Clearly, the point estimates show that the effect is also negative,

\footnotetext{
${ }^{11}$ For example, Gardner and Oswald (2007) found that in the US the medium-sized lottery prize winners display better psychological health than the control group two years after the lottery win.

${ }^{12}$ Table A.4 in the Appendix reports the results from unconditional regressions, that is, from regressions where individuals are no longer required to be employed in the year of winning a lottery prize. We expected that including these individuals would decrease potential effects of winning a lottery prize, because individuals who initially are without a job are not supposed to enter the labour market because of winning the lottery. This is indeed what we find. The (absolute) magnitudes of the parameter estimates are smaller and no longer significant in the years after winning the prize. The effect in the year of the prize win is marginally significant (at the $10 \%$ level).
} 
though small. The parameter estimate of -0.076 implies that a lottery prize of $€ 100,000$ reduces the probability to be employed by 0.76 percentage points.

From these results we infer that individuals adjust their labour supply in response to winning a lottery. Lottery prizes have a significantly negative effect on the intense margin of labour supply. With respect to the extensive-margin response the estimates are less informative. We find that the extensive margin is also negatively affected, but the estimates are characterized by wide confidence intervals so that we fail to obtain statistical significance.

\subsection{Large prizes}

In this subsection, we study how sensitive the estimated effects are to removing relatively large prizes. Notice that observations related to Jackpot prizes were already removed from the main data analyses because we have only two such observations (one of $€ 15$ million and one of $€ 22.5$ million). Our identification of the lottery prize effects in Section 3.1 comes from 81 prizes above $€ 100,000$. As shown in Table 1 , out of these 81 prizes 14 are above $€ 500,000$. It is important to know that two of the 14 prizes above $€ 500,000$ are close to $€ 600,000$ and the other 12 are close to $€ 1$ million. The majority of the prizes above $€ 100,000$ and below $€ 500,000$ are right above $€ 100,000$, and 5 are around $€ 200,000$. Table 5 reports estimation results from regressions where data points related to prizes above $€ 500,000$ are removed.

We find that removing prizes above $€ 500,000$ has the following consequences. First, the effects for $T>0$ are no longer statistically significant. Second, the magnitude of the effect of individual prizes on individual-level earnings in $T=0$ has increased to some extent. In particular, we now obtain a magnitude such that if an individual wins, for example, $€ 100,000$, labour earnings go down by about $€ 5,600$ (significant at the $10 \%$ level with permutation-based 
$p$-values). Third, the effect of prizes on earnings at the household level in $T=0$ is no longer statistically significant. These findings suggest that the above-established long-term effects of lottery prizes are driven by the prizes above $€ 500,000$. It seems that whereas the large prizes lead individuals to work less for at least four years in a row, including the year of the win, smaller prizes (mostly around $€ 100,000$ ) only have a temporary impact, namely in the year of the lottery win. In addition, these smaller prizes only have an effect at the individual level, that is, for the person who wins the lottery prize, and not so at the household level. Finally, in line with what could be expected, the effects on the probability to be employed remain small and statistically insignificant.

Table 5: Lottery prize effects excluding prizes above $€ 500,000$

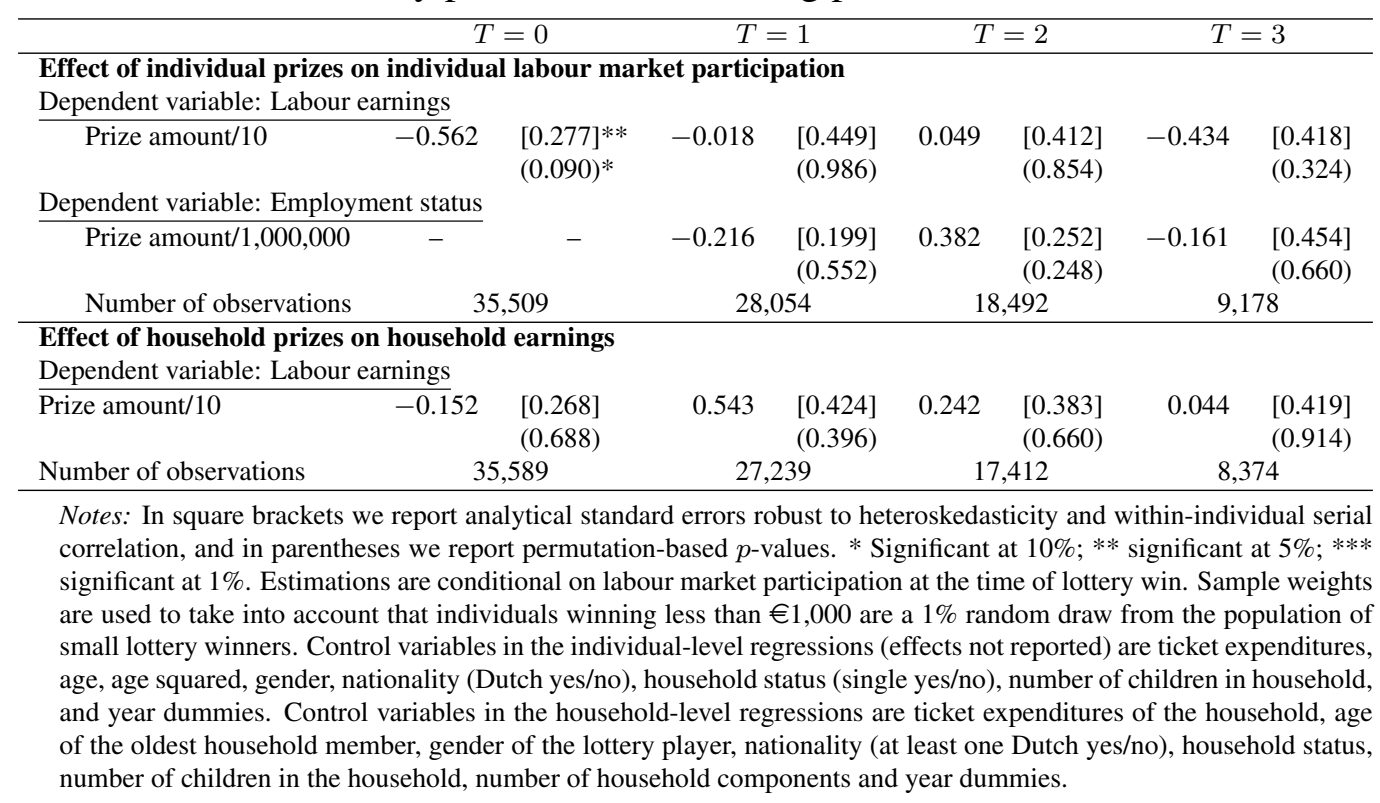

\subsection{Heterogeneity}

In this section, we slice up the data in several ways and focus on the effect of lottery prizes on labour market behaviour of different subgroups of individuals or households. In particular, we investigate the effect of individual prizes on labour market participation depending on gender, 
age (up to 50 versus older than 50), household status (non-single versus single), earnings (below versus above the median earnings of individuals), and parental status (no children versus children). At the household level we split up the effect according to household status, earnings (below versus above the median household earnings), and parental status. Results of regressions for these subgroups are presented in Table 6. The table includes results based on all prizes as well as based on prizes below $€ 500,000$. We focus on the effects on labour earnings because we could not identify a relevant effect on the probability of being employed at the aggregate level. We focus on $T=0$ because for $T>0$ the number of prizes in the subgroups becomes very low, making it problematic to identify heterogeneous effects. ${ }^{13}$

First, we focus on possible gender differences. Section $a$ of Table 6 shows that, when lottery prizes increase, labour earnings of male players tend to decrease more than female players' earnings, if prizes above $€ 500,000$ are included. In $T=0$, male earnings decrease by $€ 1,680$ after winning a prize of $€ 100,000$ whereas female earnings do not go down. The gender difference is not observed in the estimations based on prizes below $€ 500,000$ suggestomg that the gender difference is driven by very large prizes. However, the gender discrepancy disappears for $T>0$, as shown in Table A.6 in Appendix F.

Second, we turn to possible differences between age groups. Section $b$ of Table 6 shows that negative effects of lottery prizes on labour earnings are strongest for individuals who are older than 50. This can be seen in the estimations based on all prizes, as well as in those excluding prizes above $€ 500,000$. Hence, individuals older than 50 work significantly less in the year of the lottery win, whereas individuals younger than 50 are not inclined to change their work attitude. To illustrate, a prize of $€ 100,000$ reduces annual earnings of individuals older than

\footnotetext{
${ }^{13}$ For the sake of completeness, Appendix F reports results related to the effects on earnings in $T>0$ both at the individual and household level, as well as the effects on employment in $T>0$.
} 
Table 6: Heterogeneity of lottery prizes effects in $T=0$

\begin{tabular}{|c|c|c|c|c|c|c|c|c|}
\hline \multirow{4}{*}{$\begin{array}{l} \\
\text { Dependent variable: Labour earnings } \\
a \text {. By gender }\end{array}$} & \multicolumn{4}{|c|}{ Individual level } & \multicolumn{4}{|c|}{ Household level } \\
\hline & \multirow{2}{*}{\multicolumn{2}{|c|}{ All prizes }} & \multirow{2}{*}{\multicolumn{2}{|c|}{$\begin{array}{l}\text { Excluding prizes } \\
\text { larger than } € 500,000\end{array}$}} & \multirow{2}{*}{\multicolumn{2}{|c|}{ All prizes }} & \multirow{2}{*}{\multicolumn{2}{|c|}{$\begin{array}{c}\text { Excluding prizes } \\
\text { larger than } € 500,000\end{array}$}} \\
\hline & & & & & & & & \\
\hline & & & & & & & & \\
\hline Prize amount/10 if male & -0.168 & $\begin{array}{l}{[0.055]^{* * *}} \\
(0.002)^{* * *}\end{array}$ & -0.586 & $\begin{array}{l}{[0.324]^{*}} \\
(0.136)\end{array}$ & & & & \\
\hline Prize amount $/ 10$ if female & 0.031 & $\begin{array}{l}{[0.062]} \\
(0.678)\end{array}$ & -0.633 & $\begin{array}{l}{[0.520]} \\
(0.330)\end{array}$ & & & & \\
\hline$b$. By age & & & & & & & & \\
\hline Prize amount/10 if younger than 50 & -0.075 & $\begin{array}{l}{[0.053]} \\
(0.234)\end{array}$ & -0.239 & $\begin{array}{l}{[0.357]} \\
(0.602)\end{array}$ & & & & \\
\hline Prize amount/10 if older than 50 & -0.222 & $\begin{array}{l}{[0.117]^{*}} \\
(0.054)^{*}\end{array}$ & -1.055 & $\begin{array}{l}{[0.445]^{* *}} \\
(0.054)^{*}\end{array}$ & & & & \\
\hline c. By household status & & & & & & & & \\
\hline Prize amount/10 if in couple & -0.136 & $\begin{array}{l}{[0.060]^{* *}} \\
(0.034)^{* *}\end{array}$ & -0.618 & $\begin{array}{l}{[0.312]^{* *}} \\
(0.096)^{*}\end{array}$ & -0.156 & $\begin{array}{l}{[0.080]^{* *}} \\
(0.090)^{*}\end{array}$ & 0.225 & $\begin{array}{l}{[0.323]} \\
(0.686)\end{array}$ \\
\hline $\begin{array}{l}\text { Prize amount } / 10 \text { if single } \\
\text { d. By earnings }\end{array}$ & -0.070 & $\begin{array}{l}{[0.085]} \\
(0.546)\end{array}$ & -0.519 & $\begin{array}{l}{[0.597]} \\
(0.518)\end{array}$ & -0.037 & $\begin{array}{l}{[0.076]} \\
(0.770)\end{array}$ & -0.132 & $\begin{array}{l}{[0.255]} \\
(0.934)\end{array}$ \\
\hline 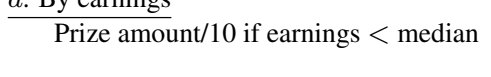 & -0.076 & $\begin{array}{l}{[0.045]^{*}} \\
(0.038)^{* *}\end{array}$ & -0.195 & $\begin{array}{l}{[0.187]} \\
(0.358)\end{array}$ & -0.064 & $\begin{array}{l}{[0.049]} \\
(0.166)\end{array}$ & -0.107 & $\begin{array}{l}{[0.229]} \\
(0.734)\end{array}$ \\
\hline Prize amount/10 if earnings $>$ median & -0.139 & $\begin{array}{l}{[0.035]^{* * *}} \\
(0.042)^{* *}\end{array}$ & -0.713 & $\begin{array}{l}{[0.338]^{* *}} \\
(0.096)^{*}\end{array}$ & -0.137 & $\begin{array}{l}{[0.064]^{*}} \\
(0.258)\end{array}$ & -0.146 & $\begin{array}{l}{[0.307]} \\
(0.794)\end{array}$ \\
\hline e. By parental status & & & & & & & & \\
\hline Prize amount/10 if no children & -0.144 & $\begin{array}{l}{[0.080]^{*}} \\
(0.058)^{*}\end{array}$ & -0.872 & $\begin{array}{l}{[0.363]^{* *}} \\
(0.060)^{*}\end{array}$ & -0.047 & $\begin{array}{l}{[0.108]} \\
(0.672)\end{array}$ & 0.014 & $\begin{array}{l}{[0.323]} \\
(0.942)\end{array}$ \\
\hline Prize amount/10 if children & -0.116 & $\begin{array}{l}{[0.066]^{*}} \\
(0.096)^{*}\end{array}$ & -0.368 & $\begin{array}{l}{[0.438]} \\
(0.482)\end{array}$ & -0.191 & $\begin{array}{l}{[0.065]^{* * *}} \\
(0.068)^{*}\end{array}$ & 0.266 & $\begin{array}{l}{[0.415]} \\
(0.708)\end{array}$ \\
\hline Number of observations & \multicolumn{2}{|c|}{35,523} & \multicolumn{2}{|c|}{35,509} & \multicolumn{2}{|c|}{35,603} & \multicolumn{2}{|c|}{35,589} \\
\hline
\end{tabular}

50 by about $€ 2,200$. With annual earnings of about $€ 40,000$, this implies that the working time of individuals older than 50 are reduced by about 2 hours per week or 2-3 weeks per year. Given that the different effects depending on age are consistent across the two sets of regression results (including and excluding prizes above $€ 500,000$ ), and the differences persist in years after the lottery win when including or excluding prizes above $€ 500,000$ (see Tables A.6 and A.7 in Appendix F), we take this result as a relatively robust finding.

Third, consider the results depending on household status. Section $c$ of Table 6 shows that only individuals who live in a couple work significantly less in the year of a prize winning, whereas no significant effect is established for singles. This can be seen in the individual-level estimations based on all prizes as well as in those excluding prizes above $€ 500,000$. Notice, 
however, that the power to reject the null is rather low in the regressions excluding prizes above $€ 500,000$. In the household-level regressions, we get a marginally significant effect for couples only when all prizes are included.

Fourth, section $d$ of Table 6 shows that the negative effect of lottery prizes is more pronounced for individuals who have higher than median income. This is the case when all prizes are included as well as when prizes above $€ 500,000$ are excluded. Again, the power to reject the null is rather low in the regressions excluding prizes above $€ 500,000$. Similar tendencies are observed in the household-level regressions, albeit not statistically significant.

Finally, section $e$ of Table 6 shows that the negative effect of lottery prizes is more pronounced for individuals who do not have children than for individuals who have children. Given that the difference clearly shows up when both including and excluding prizes above $€ 500,000$ and persists in the years after the lottery win when including or excluding prizes above $€ 500,000$ (see Table A.6 in Appendix F), we take this as a relatively robust finding. ${ }^{14}$

As shown in Table 6, results are less clear-cut at the household level. When all prizes are included, the effects at the household level for $T=0$ are very similar to the effects at the individual level although at the household level the parameters are only significant for couples and high-earners. After removing the largest prizes from our sample none of the parameter estimates is significantly different from zero at the household level. The reason may be that there are compensating effects, i.e. the partner of the prize winner (who works less hours) works slightly more hours. It is more likely, however, that effects are simply blurred at the household level because there are no spillover effects of the relatively small prizes (prizes below $€ 500,000$ ). Following up on this, we investigated in the spirit of Cesarini et al. (2015)

\footnotetext{
${ }^{14}$ As shown in Table A.6 in Appendix F, the parameter estimates for individuals without children are negative also for $T>0$, and are relatively large in magnitude, even when prizes above $€ 500,000$ are removed.
} 
whether there are "spillover" effects from the spouse in a family winning a prize. We found no evidence of such spillover effects (see Table A.10 in Appendix G).

We cautiously conclude from the heterogeneity analysis that it is mostly individuals older than 50 and individuals who have no children who reduce their working hours after a lottery win.

\section{Conclusions}

The labour market behaviour of lottery prize winners is informative about labour supply responses to exogenous income shocks. We study labour supply responses of winners of lottery prizes in the Netherlands. We find that winning a lottery prize has an economically meaningful and statistically significant effect on the intensive margin of labour supply, i.e. on labour earnings. If an individual wins a substantial lottery prize, the effect on earnings is present for several years. If we remove prizes above $€ 500,000$ from our sample, we only observe an earnings effect in the year of the winning. Furthermore, we find that winning a substantial lottery prize has no significant effects on the extensive margin of labour supply. Although the imprecision of our estimates is probably related to the limited number of lottery winnings, the obtained point estimates are rather small.

When interpreting the results of our empirical analysis, the labour market situation in the Netherlands needs to be taken into account. In a labour market with high unemployment, employed individuals might not want to take the risk to temporarily withdraw from the labour market for fear of having great difficulties to find a job later on. This is not the case in the Netherlands where in the period of analysis unemployment rates were low. According to OECD statistics, over the period of analysis the average unemployment rate in the Netherlands ranged 
from 3 to 5 percent, well below the OECD average. And, as discussed in the introduction, in the Netherlands it is not so difficult to adjust labour supply along the intensive margin. Part-time work is quite common. Most likely, to be able to smooth labour supply, winners of large prizes save a substantial part of their lottery wins. Apparently, these winners decide to benefit from their prizes for several years in a row. They seem to reduce working hours only by a few hours per week, or alternatively by taking more days off and taking longer holidays. If we remove prizes above $€ 500,000$ there is only an immediate effect on earnings. Apparently, part of these prizes is consumed immediately in the form of leisure.

Marche Polytechnic University, CentER, IZA

Tilburg University, CentER, CEPR

Erasmus University Rotterdam, University of Melbourne, Tinbergen Institute, CEPR, IZA

\section{References}

Arvey, R.D., Harpaz, I. and Liao, H. (2004). 'Work centrality and post-award work behavior of lottery winners', Journal of Psychology: Interdisciplinary and Applied, vol. 138, pp. 404420.

Booth, A.L. and van Ours, J.C. (2013). 'Part-time jobs: what women want?', Journal of Population Economics, vol. 26, pp. 263-283.

Box, G. and Andersen, S. (1955). 'Permutation theory in the derivation of robust criteria and the study of departures from assumption', Journal of the Royal Statistical Society Series B, vol. 17, pp. 1-34. 
Brown, J.R., Coile, C.C. and Weisbenner, S.J. (2010). 'The effect of inheritance receipt on retirement', Review of Economics and Statistics, vol. 92, pp. 425-434.

Cesarini, D., Lindqvist, E., Notowidigdo, M. and Östling, R. (2015). 'The effect of wealth on individual and household labor supply: Evidence from Swedish lotteries', NBER Working Paper 21762.

Cesarini, D., Lindqvist, E., Östling, R. and Wallace, B. (2016). 'Wealth, health, and child development: Evidence from administrative data on Swedish lottery players', Quarterly Journal of Economics, vol. 131, pp. 687-738.

Fisher, R. (1935). The Design of Experiments, Edinburg: Oliver \& Boyd.

Furaker, B. and Hedenus, A. (2009). 'Gambling windfall decisions: Lottery winners and employment behavior', Gaming Research \& Review Journal, vol. 13, pp. 1-15.

Gardner, J. and Oswald, A. (2007). 'Money and mental wellbeing: A longitudinal study of medium-sized lottery wins', Journal of Health Economics, vol. 26, pp. 49-60.

Goodstein, R. (2008). ‘The effect of wealth on labor force participation of older men', Discussion Paper University of North Carolina at Chapel Hill.

Hedenus, A. (2009). 'Time for work or time for family? Work-life balance after winning the lottery', World Leisure Journal, vol. 51, pp. 27-38.

Hedenus, A. (2012). 'Who wants to work less? Significance of socio-economic status and work conditions for work commitment among Swedish lottery winners', Acta Sociologica, vol. 55, pp. 335-350. 
Hurd, M.D., Reti, M. and Rohwedder, S. (2009). 'The effect of large capital gains or losses on retirement', in (D. A. Wise, ed.), Developments in the Economics of Aging, pp. 127-163, chap. 4, National Bureau of Economic Research.

Imbens, G., Rubin, D. and Sacerdote, B. (2001). 'Estimating the effect of unearned income on labor earnings, savings, and consumption: Evidence from a survey of lottery players', American Economic Review, vol. 91, pp. 778-794.

Jacob, B.A. and Ludwig, J. (2012). 'The effects of housing assistance on labor supply: Evidence from a voucher lottery', American Economic Review, vol. 102, pp. 272-304.

Joulfaian, D. and Wilhelm, M. (1994). 'Inheritances and labor supply', Journal of Human Resources, vol. 29, pp. 1205-1234.

Kaplan, H.R. (1987). 'Lottery winners: The myth and reality', Journal of Gambling Behavior, vol. 3, pp. 168-178.

Keane, M.P. (2011). 'Labor supply and taxes: A survey', Journal of Economic Literature, vol. 49, pp. 961-1075.

Kuhn, P., Kooreman, P., Soetevent, A.R. and Kapteyn, A. (2011). 'The own and social effects of an unexpected income shock: Evidence from the Dutch Postcode Lottery', American Economic Review, vol. 101, pp. 2226-2247.

Roeters, A. and Craig, L. (2014). 'Part-time work, women's work-life conflict, and job satisfaction: a cross-national comparison of Australia, the Netherlands, Germany, Sweden, and the United Kingdom', International Journal of Comparative Sociology, vol. 55, pp. 185-203. 
Visser, J., Wilthagen, T., Beltzer, R. and Koot-van der Putte, E. (2004). 'The Netherlands: from atypicality to typicality', in (S. Sciarra, P. Davies and M. Freedland, eds.), Employment Policy and the Regulation of Part-time Work in the European Union; A Comparative Analysis, pp. 190-223, Cambridge, Cambridge University Press.

Welch, W. (1990). 'Construction of permutation tests', Journal of the American Statistical Association, vol. 411, pp. 693-698. 


\section{Appendix}

\section{A Prize structure of the State Lottery}

Table A.1: Prize structure of the State Lottery

\begin{tabular}{lcc}
\hline Prize amount & Correct letters/numbers & Number of combinations \\
\hline$€ 7,500,000$ & 8 & 1 \\
$€ 1,000,000$ & 8 & 1 \\
$€ 100,000$ & 8 & 10 \\
$€ 25,000$ & 8 & 10 \\
$€ 10,000$ & 8 & 20 \\
$€ 1,000$ & 5 & 5 \\
$€ 450$ & 5 & 7 \\
$€ 250$ & 5 & 7 \\
$€ 100$ & 5 & 8 \\
$€ 30$ & 2 & 3 \\
$€ 20$ & 1 & 1 \\
$€ 10$ & 1 & 1 \\
$€ 7.5$ & 1 & 2 \\
$€ 5$ & 1 & 1 \\
\hline
\end{tabular}

Notes: This table gives an overview of the current prize structure in the State Lottery. This prize structure has been relatively constant since 2005 .

\section{B Summary statistics of the Dutch population}

Table A.2: Summary statistics of the Dutch population

\begin{tabular}{lrr}
\hline & Our sample $(T=0)$ & Dutch Population (year 2005) \\
\hline Labour earnings/primary income $(€)$ & 37,093 & 38,000 \\
Female & 0.32 & 0.50 \\
Age (years) & 45.3 & 46.9 \\
\# children & 0.95 & 1.04 \\
Dutch & 0.97 & 0.75 \\
Single & 0.20 & 0.35 \\
\hline Observations & 35,523 & $7,042,000$ \\
\hline
\end{tabular}

Notes: Labour earnings are gross earnings; primary earnings for the population include earnings and income from savings and profits; age population: average of population 18 years and older; "\# children" stands for the number of children in the household. All the monetary values are in real terms $(\mathrm{CPI}$ in $2005=100)$. The number of observations of the population refers to the number of households; there were 16.3 million inhabitants in total, of which 12.7 million were 18 years or older. Source: Statistics Netherlands 


\section{Full set of estimation results}

Table A.3: Lottery prize effects on earnings conditional on labour market participation at time of win (full)

\begin{tabular}{|c|c|c|c|c|c|c|c|c|c|c|c|c|}
\hline & \multicolumn{3}{|c|}{$T=0$} & \multicolumn{3}{|c|}{$T=1$} & \multicolumn{3}{|c|}{$T=2$} & \multicolumn{3}{|c|}{$T=3$} \\
\hline & \multicolumn{2}{|l|}{ Coeff. } & Std. Err. & \multicolumn{2}{|l|}{ Coeff. } & \multirow[t]{2}{*}{ Std. Err. } & \multicolumn{2}{|l|}{ Coeff. } & \multirow[t]{2}{*}{ Std. Err. } & \multicolumn{2}{|l|}{ Coeff. } & \multirow[t]{2}{*}{ Std. Err. } \\
\hline \multicolumn{10}{|c|}{$\begin{array}{l}\text { Effect of individual prizes on individual labour market participation } \\
\text { Dependent variable: Labour earnings }\end{array}$} & & & \\
\hline Prize amount & -0.0116 & $* *$ & 0.0050 & -0.0116 & * & 0.0069 & -0.0164 & $* * *$ & 0.0058 & -0.0177 & **** & 0.0062 \\
\hline Ticket expenditure & 10.6862 & $* * *$ & 2.1469 & 11.5929 & $* * *$ & 2.6187 & 12.4920 & $* * *$ & 3.0141 & 1.0042 & **** & 0.3252 \\
\hline Female & $-17,490.7400$ & $* * *$ & 466.3942 & $-18,820.6300$ & $* * *$ & 530.8459 & $-18,578.7500$ & $* * *$ & 559.1594 & $-18,576.1400$ & **** & 605.6606 \\
\hline Age & $3,396.6220$ & $* * *$ & 214.3667 & $4,207.8120$ & $* * *$ & 255.2251 & $4,898.6990$ & $* * *$ & 268.6920 & $5,404.3550$ & **** & 293.4588 \\
\hline Age squared & $-3,744.2190$ & $* * *$ & 246.4052 & $-4,784.3760$ & $* * *$ & 301.8347 & $-5,730.9690$ & $* * *$ & 314.8177 & $-6,490.2370$ & $* * *$ & 341.1067 \\
\hline \# children & -96.7395 & & 264.5375 & 195.3832 & & 334.9954 & 211.1027 & & 345.6120 & 272.9508 & & 375.5471 \\
\hline Dutch & 224.4454 & & $1,424.7590$ & 77.6804 & & $1,648.3870$ & 507.3603 & & $1,735.5080$ & -297.6902 & & $1,942.1980$ \\
\hline Single & $-1,493.6380$ & $* * *$ & 551.1285 & $-2,100.0620$ & $* * *$ & 646.4357 & $-2,165.062$ & $* * *$ & 683.7948 & $-1,913.2930$ & $* *$ & 772.5419 \\
\hline \multicolumn{13}{|l|}{ Time dummies } \\
\hline 2006 & $1,651.3050$ & $* * *$ & 182.3138 & - & & - & - & & - & - & & - \\
\hline 2007 & $2,255.5950$ & $* * *$ & 219.3624 & $1,069.7310$ & **** & 243.3967 & 865.8302 & $* * *$ & 262.0515 & - & & - \\
\hline 2008 & $3,006.4220$ & $* * *$ & 239.2758 & $1,747.9100$ & $* * *$ & 279.7827 & - & & - & - & & - \\
\hline Constant & $-34,814.5200$ & $* * *$ & $4,655.3990$ & $-47,524.1200$ & $* * *$ & $5,394.0130$ & $-59,272.4800$ & $* * *$ & $5,675.0220$ & $-64,892.9100$ & **** & $6,252.1760$ \\
\hline$R^{2}$ & \multicolumn{3}{|c|}{0.1798} & \multicolumn{3}{|c|}{0.1466} & \multicolumn{3}{|c|}{0.1513} & \multicolumn{3}{|c|}{0.1642} \\
\hline Dependent variable: Empl & ment status & & & & & & & & & & & \\
\hline Prize amount & - & & - & $-7.59 \mathrm{e}-08$ & & $1.08 \mathrm{e}-07$ & $-6.33 e-08$ & & $1.25 \mathrm{e}-07$ & $-1.89 e-07$ & & $2.02 \mathrm{e}-07$ \\
\hline Ticket expenditure & - & & - & $-4.98 \mathrm{e}-06$ & & $1.30 \mathrm{e}-05$ & $-7.80 \mathrm{e}-06$ & & $1.79 \mathrm{e}-05$ & $-1.68 \mathrm{e}-06$ & & $3.61 \mathrm{e}-06$ \\
\hline Female & - & & - & -0.0046 & & 0.0030 & -0.0068 & & 0.0053 & -0.0091 & & 0.0075 \\
\hline Age & - & & - & 0.0212 & $* * *$ & 0.0017 & 0.0356 & $* * *$ & 0.0030 & 0.0520 & **** & 0.0042 \\
\hline Age squared & - & & - & -0.0266 & $* * *$ & 0.0020 & -0.0450 & $* * *$ & 0.0036 & -0.0662 & $* * *$ & 0.0050 \\
\hline \# children & - & & - & -0.0028 & $* *$ & 0.0014 & -0.0040 & & 0.0026 & -0.0040 & & 0.0034 \\
\hline Dutch & - & & - & 0.0152 & * & 0.0084 & 0.0293 & $*$ & 0.0155 & 0.0353 & & 0.0219 \\
\hline Single & - & & - & -0.0102 & $* * *$ & 0.0039 & -0.0128 & $*$ & 0.0069 & -0.0107 & & 0.0096 \\
\hline Time dummies & & & & & & & & & & & & \\
\hline 2006 & - & & - & - & & - & - & & - & - & & - \\
\hline 2007 & - & & - & 0.0084 & ** & 0.0033 & 0.0038 & & 0.0032 & - & & - \\
\hline 2008 & - & & - & 0.0049 & & 0.0034 & - & & - & - & & - \\
\hline Constant & - & & - & 0.5633 & $* * *$ & 0.0364 & 0.2720 & $* * *$ & 0.0633 & -0.0467 & & 0.0865 \\
\hline$R^{2}$ & & - & & & 0.0342 & & & 0617 & & & 0.0986 & \\
\hline Observations & & 35,523 & & & 24,548 & & & ,499 & & & 9,182 & \\
\hline$\frac{\text { Dependent vari }}{\text { Prize amount }}$ & $\stackrel{\operatorname{lgs}}{-}_{0.0179}$ & $* * *$ & 0.0065 & -0.0226 & $* *$ & 0.0109 & -0.0239 & $* *$ & 0.0117 & -0.0155 & & 0.0117 \\
\hline Ticket expenditure & 13.5463 & $* * *$ & 2.5249 & 18.4404 & $* * *$ & 3.0436 & 19.3334 & $* * *$ & 3.4961 & 18.6274 & **** & 3.6732 \\
\hline Average age & $4,575.0280$ & $* * *$ & 291.1664 & $4,903.5410$ & $* * *$ & 334.9621 & $5,086.3590$ & $* * *$ & 386.7132 & $5,266.5370$ & **** & 450.3485 \\
\hline Average age squared & -49.6951 & $* * *$ & 3.2907 & -54.5114 & $* * *$ & 3.8115 & -57.9962 & $* * *$ & 4.4066 & -61.74877 & **** & 5.1473 \\
\hline \# children & $-7,883.9580$ & $* * *$ & $1,425.9830$ & $-4,058.728$ & $* * *$ & $1,362.4800$ & $-3,603.3820$ & $* *$ & $1,421.5500$ & $-2,768.1760$ & * & $1,649.4610$ \\
\hline \# household components & $9,009.5200$ & $* * *$ & $1,395.2090$ & $5,945.4280$ & $* * *$ & $1,287.431$ & $5,592.7660$ & & $1,356.8460$ & $5,073.6930$ & **** & $1,578.3330$ \\
\hline Dutch & $9,140.913$ & $* * *$ & $2,628.284$ & $8,919.1950$ & $* * *$ & $2,662.9300$ & $5,460.6720$ & * & $3,085.2530$ & $4,409.0390$ & & $3,380.0160$ \\
\hline Single & $-16,011.3000$ & $* * *$ & 1539.7310 & $-16,376.02$ & $* * *$ & $1,498.2130$ & $-14,527.5700$ & $* * *$ & $1,646.2010$ & $-13,067.1800$ & **** & $1,959.6600$ \\
\hline Time dummies & & & & & & & & & & & & \\
\hline 2006 & $2,643.7330$ & $* * *$ & 254.5873 & - & & - & - & & - & - & & - \\
\hline 2007 & $3,782.6300$ & $* * *$ & 309.0081 & $1,466.3300$ & $* * *$ & 291.6400 & $1,373.2990$ & $* * *$ & 337.7023 & - & & - \\
\hline 2008 & $5,314.1640$ & $* * *$ & 342.0275 & $3,088.2880$ & $* * *$ & 372.9806 & - & & - & - & & - \\
\hline Constant & $-73,163.8500$ & $* * *$ & $7,131.9950$ & -69902.1100 & $* * *$ & $7,898.3770$ & $--65,517.8900$ & $* * *$ & $8,953.0890$ & $-62,850.1100$ & **** & $10,256.0900$ \\
\hline$R^{2}$ & & .1694 & & & 0.1221 & & & 1075 & & & 0.1011 & \\
\hline Observations & & 45,603 & & & 27,246 & & & ,417 & & & 8,376 & \\
\hline
\end{tabular}

Notes: * significant at $10 \% ; *$ significant at $5 \%$; *** significant at $1 \%$. Estimations are conditional on labour market participation at the time of the lottery win(s). Sample weights are used to
that individuals winning less than $€ 1,000$ are a $1 \%$ random draw from the population of small lottery winners. Analytical standard errors are robust to heteroskedasticity and serial correlation. 


\section{Estimation results unconditional on labour market participation at the}

\section{time of lottery win}

Table A.4: Lottery prize effects unconditional on labour market participation at time of win

\begin{tabular}{|c|c|c|c|c|c|c|c|c|}
\hline & \multicolumn{2}{|c|}{$T=0$} & \multicolumn{2}{|c|}{$T=1$} & \multicolumn{2}{|c|}{$T=2$} & \multicolumn{2}{|c|}{$T=3$} \\
\hline \multicolumn{9}{|c|}{ Dependent variable: Labour earnings } \\
\hline Prize amount $/ 10$ & -0.090 & $\begin{array}{l}{[0.050]^{* *}} \\
(0.072)^{*}\end{array}$ & -0.070 & $\begin{array}{l}{[0.069]^{*}} \\
(0.314)\end{array}$ & -0.113 & $\begin{array}{l}{[0.058]^{* * * *}} \\
(0.138)\end{array}$ & -0.118 & $\begin{array}{l}{[0.062]^{* * * *}} \\
(0.184)\end{array}$ \\
\hline \multicolumn{9}{|c|}{ Dependent variable: Employment status } \\
\hline Prize amount $/ 1,000,000$ & - & - & -0.106 & $\begin{array}{l}{[0.106]} \\
(0.352)\end{array}$ & -0.119 & $\begin{array}{l}{[0.100]} \\
(0.326)\end{array}$ & -0.195 & $\begin{array}{l}{[0.122]} \\
(0.208)\end{array}$ \\
\hline Number of observations & & 326 & & 245 & & 357 & & 644 \\
\hline
\end{tabular}

Notes: In square brackets we report analytical standard errors robust to heteroskedasticity and within-individual serial correlation, and in parentheses we report permutation-based $p$-values. * Significant at $10 \%$; ** significant at $5 \%$; *** significant at $1 \%$. Sample weights are used to take into account that individuals winning less than $€ 1,000$ are a $1 \%$ random draw from the population of small lottery winners. 


\section{E Tests of random assignment of lottery prizes}

Table A.5 reports the estimation results of the equation for the lottery prizes. The covariates are those used in the benchmark model. They are measured in the same year of the lottery win. If the assumption of random assignment of lottery prizes holds, conditional on lottery expenditures and year fixed effects, the six personal covariates (gender, age, age squared, number of children, nationality, and household status) should not be individually and jointly significant in explaining the lottery prizes. We find that the coefficients of the personal covariates are never significantly different from zero, both individually and jointly. This provides support for the random assignments of the lottery prizes. The lottery expenditures are positively correlated to the lottery prizes: each Euro invested in lottery tickets returns about $€ 0.47-€ 0.49$. Finally, the time fixed effects are important in explaining the lottery prizes. This is due to the fact the Dutch State Lottery changed the structure of the lottery prizes across years. The year dummies capture these shocks in the prize structure. These random assignment tests reject the null hypothesis, if we do not include the ticket expenditures and the year fixed effects among the regressors. ${ }^{15}$

Table A.5: Estimation results of the regression of lottery prizes on covariates

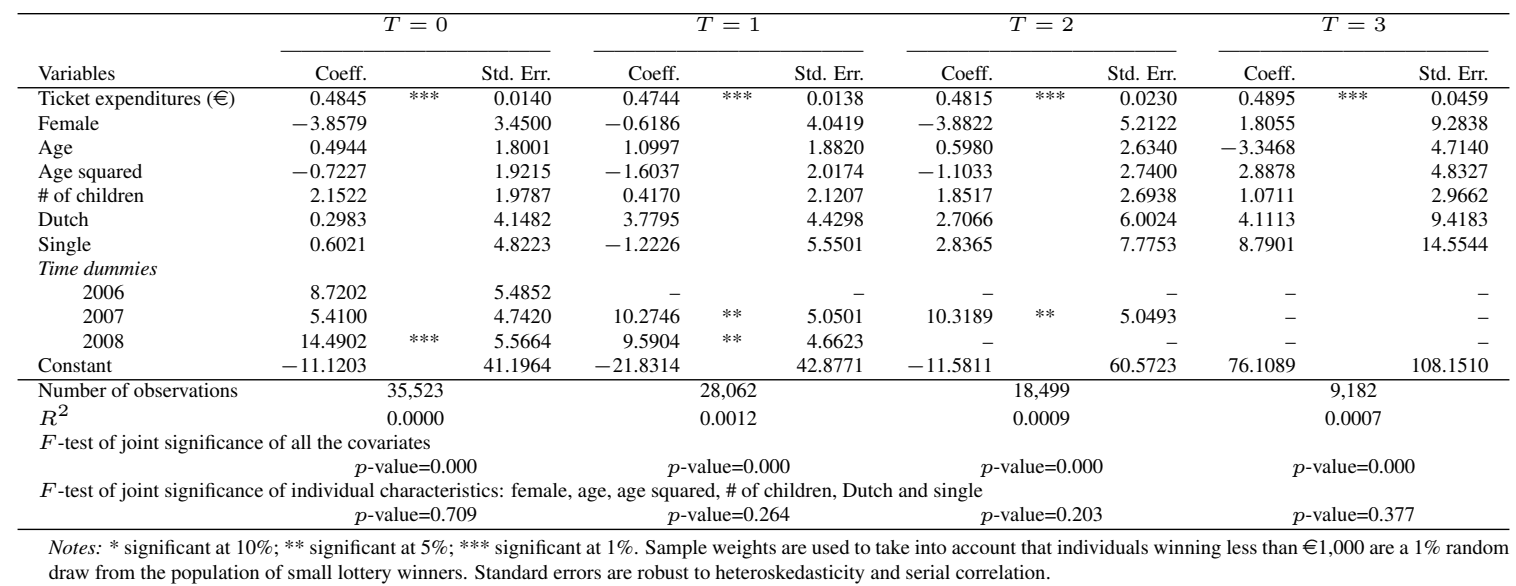

\footnotetext{
${ }^{15}$ The joint significance tests of the six individual characteristics, if the ticket expenditures and the year fixed effects are not included in the equation for the lottery prizes, return the following $p$-values: 0.007 with $T=0$; 0.001 with $T=1 ; 0.027$ with $T=2 ; 0.458$ with $T=3$.
} 


\section{F Heterogeneity estimations including $T>0$}

Table A.6: Heterogeneity of the effect of individual lottery prizes on individual labour market participation (including $T>0$ )

\begin{tabular}{|c|c|c|c|c|c|c|c|c|}
\hline Dependent variable: Labour earnings & \multicolumn{2}{|c|}{$T=0$} & \multicolumn{2}{|c|}{$T=1$} & \multicolumn{2}{|c|}{$T=2$} & \multicolumn{2}{|c|}{$T=3$} \\
\hline \multicolumn{9}{|l|}{$a$. By gender } \\
\hline Prize amount $/ 10$ if male & -0.168 & $\begin{array}{l}{[0.055]^{* * *}} \\
(0.002)^{* * *}\end{array}$ & -0.140 & $\begin{array}{l}{[0.085]^{*}} \\
(0.154)\end{array}$ & -0.185 & $\begin{array}{l}{[0.073] * *} \\
(0.090)^{*}\end{array}$ & -0.204 & $\begin{array}{l}{[0.105]^{*}} \\
(0.210)\end{array}$ \\
\hline Prize amount $/ 10$ if female & 0.031 & $\begin{array}{l}{[0.062]} \\
(0.678)\end{array}$ & -0.119 & $\begin{array}{l}{[0.088]} \\
(0.368)\end{array}$ & -0.164 & $\begin{array}{l}{[0.098]^{*}} \\
(0.116)\end{array}$ & -0.153 & $\begin{array}{l}{[0.097]} \\
(0.144)\end{array}$ \\
\hline \multicolumn{9}{|l|}{$b$. By age } \\
\hline Prize amount/10 if younger than 50 & -0.075 & $\begin{array}{l}{[0.053]} \\
(0.234)\end{array}$ & -0.141 & $\begin{array}{l}{[0.065]^{* *}} \\
(0.094)^{*}\end{array}$ & -0.188 & $\begin{array}{l}{[0.055]^{* * *}} \\
(0.014)^{* *}\end{array}$ & -0.169 & $\begin{array}{l}{[0.057]^{* * *}} \\
(0.108)\end{array}$ \\
\hline Prize amount $/ 10$ if older than 50 & -0.222 & $\begin{array}{l}{[0.117]^{*}} \\
(0.054)^{*}\end{array}$ & 0.028 & $\begin{array}{l}{[0.208]} \\
(0.820)\end{array}$ & -0.044 & $\begin{array}{l}{[0.155]} \\
(0.964)\end{array}$ & -0.598 & $\begin{array}{l}{[0.621]} \\
(0.412)\end{array}$ \\
\hline \multicolumn{9}{|l|}{ c. By household status } \\
\hline Prize amount/10 if living in a couple & -0.136 & $\begin{array}{l}{[0.060]^{* *}} \\
(0.034)^{* *}\end{array}$ & -0.092 & $\begin{array}{l}{[0.076]} \\
(0.422)\end{array}$ & -0.135 & $\begin{array}{l}{[0.077]^{*}} \\
(0.218)\end{array}$ & -0.137 & $\begin{array}{l}{[0.093]} \\
(0.434)\end{array}$ \\
\hline Prize amount/10 if single & -0.070 & $\begin{array}{l}{[0.085]} \\
(0.546)\end{array}$ & -0.201 & $\begin{array}{l}{[0.136]} \\
(0.140)\end{array}$ & -0.254 & $\begin{array}{l}{[0.062]^{* * *}} \\
(0.052)^{*}\end{array}$ & -0.213 & $\begin{array}{l}{[0.073]^{* * * *}} \\
(0.146)\end{array}$ \\
\hline \multicolumn{9}{|l|}{ d. By earnings } \\
\hline Prize amount $/ 10$ if earnings $<$ median & -0.076 & $\begin{array}{l}{[0.045]^{*}} \\
(0.038)^{* *}\end{array}$ & -0.090 & $\begin{array}{l}{[0.056]} \\
(0.130)\end{array}$ & -0.104 & $\begin{array}{l}{[0.032]^{* * *}} \\
(0.054)^{*}\end{array}$ & -0.031 & $\begin{array}{l}{[0.031]} \\
(0.642)\end{array}$ \\
\hline Prize amount $/ 10$ if earnings $>$ median & -0.139 & $\begin{array}{l}{[0.035]^{* * *}} \\
(0.042)^{* *}\end{array}$ & -0.119 & $\begin{array}{l}{[0.094]} \\
(0.400)\end{array}$ & -0.241 & $\begin{array}{l}{[0.112]^{* *}} \\
(0.092)^{*}\end{array}$ & -0.481 & $\begin{array}{l}{[0.128]^{* * *}} \\
(0.040)^{* * *}\end{array}$ \\
\hline \multicolumn{9}{|l|}{ e. By parental status } \\
\hline Prize amount $/ 10$ if no children & -0.144 & $\begin{array}{l}{[0.080]^{*}} \\
(0.058)^{*}\end{array}$ & -0.214 & $\begin{array}{l}{[0.131]} \\
(0.128)\end{array}$ & -0.115 & $\begin{array}{l}{[0.071]} \\
(0.378)\end{array}$ & -0.226 & $\begin{array}{l}{[0.069]^{* * * * *}} \\
(0.128)\end{array}$ \\
\hline Prize amount $/ 10$ if presence of children & -0.116 & $\begin{array}{l}{[0.066]^{*}} \\
(0.096)^{*}\end{array}$ & -0.086 & $\begin{array}{l}{[0.090]} \\
(0.414)\end{array}$ & -0.239 & $\begin{array}{l}{[0.067]^{* * *}} \\
(0.032)^{* *}\end{array}$ & -0.175 & $\begin{array}{l}{[0.110]} \\
(0.294)\end{array}$ \\
\hline \multicolumn{9}{|l|}{ Dependent variable: Employment status } \\
\hline \multicolumn{9}{|l|}{$a$. By gender } \\
\hline Prize amount $/ 1,000,000$ if male & & & -0.124 & $\begin{array}{l}{[0.140]} \\
(0.134)\end{array}$ & 0.052 & $\begin{array}{l}{[0.034]} \\
(0.652)\end{array}$ & -0.025 & $\begin{array}{l}{[0.112]} \\
(0.624)\end{array}$ \\
\hline Prize amount $/ 1,000,000$ if female & & & 0.064 & $\begin{array}{l}{[0.038]^{*}} \\
(0.738)\end{array}$ & -0.365 & $\begin{array}{l}{[0.334]} \\
(0.172)\end{array}$ & -0.367 & $\begin{array}{l}{[0.336]} \\
(0.152)\end{array}$ \\
\hline \multicolumn{9}{|l|}{$b$. By age } \\
\hline Prize amount $/ 1,000,000$ if younger than 50 & & & -0.099 & $\begin{array}{l}{[0.125]} \\
(0.194)\end{array}$ & -0.100 & $\begin{array}{l}{[0.143]} \\
(0.278)\end{array}$ & -0.216 & $\begin{array}{l}{[0.203]} \\
(0.094)^{*}\end{array}$ \\
\hline Prize amount $/ 1,000,000$ if older than 50 & & & -0.059 & $\begin{array}{l}{[0.077]} \\
(0.904)\end{array}$ & 0.080 & $\begin{array}{l}{[0.124]} \\
(0.880)\end{array}$ & -0.112 & $\begin{array}{l}{[0.788]} \\
(0.894)\end{array}$ \\
\hline \multicolumn{9}{|l|}{ c. By household status } \\
\hline Prize amount $/ 1,000,000$ if living in a couple & & & 0.025 & $\begin{array}{l}{[0.023]} \\
(0.940)\end{array}$ & 0.060 & $\begin{array}{l}{[0.035]^{*}} \\
(0.590)\end{array}$ & 0.010 & $\begin{array}{l}{[0.101]} \\
(0.800)\end{array}$ \\
\hline Prize amount $/ 1,000,000$ if single & & & -0.378 & $\begin{array}{l}{[0.326]} \\
(0.104)\end{array}$ & -0.388 & $\begin{array}{l}{[0.344]} \\
(0.102)\end{array}$ & -0.417 & $\begin{array}{l}{[0.347]} \\
(0.132)\end{array}$ \\
\hline \multicolumn{9}{|l|}{$d$. By earnings } \\
\hline Prize amount $/ 1,000,000$ if earnings $<$ median & & & -0.166 & $\begin{array}{l}{[0.202]} \\
(0.242)\end{array}$ & 0.110 & $\begin{array}{l}{[0.047]^{* *}} \\
(0.304)\end{array}$ & 0.073 & $\begin{array}{l}{[0.060]} \\
(0.079)\end{array}$ \\
\hline Prize amount $/ 1,000,000$ if earnings $>$ median & & & 0.017 & $\begin{array}{l}{[0.020]} \\
(0.912)\end{array}$ & -0.293 & $\begin{array}{l}{[0.245]} \\
(0.054)^{*}\end{array}$ & -0.871 & $\begin{array}{l}{[0.155]^{* * *}} \\
(0.014)^{* * *}\end{array}$ \\
\hline \multicolumn{9}{|l|}{ e. By parental status } \\
\hline Prize amount $/ 1,000,000$ if no children & & & -0.245 & $\begin{array}{l}{[0.241]} \\
(0.136)\end{array}$ & 0.067 & $\begin{array}{l}{[0.046]} \\
(0.708)\end{array}$ & 0.016 & $\begin{array}{l}{[0.074]} \\
(0.804)\end{array}$ \\
\hline Prize amount $/ 1,000,000$ if presence of children & & & 0.029 & $\begin{array}{l}{[0.015]^{*}} \\
(0.730)\end{array}$ & -0.172 & $\begin{array}{l}{[0.206]} \\
(0.210)\end{array}$ & -0.416 & $\begin{array}{l}{[0.339]} \\
(0.074)^{*}\end{array}$ \\
\hline Number of observations & & 523 & & 62 & & 499 & & 182 \\
\hline
\end{tabular}


Table A.7: Heterogeneity of the effect of individual lottery prizes on individual labour market participation excluding prizes above $€ 500,000$ (including $T>0$ )

\begin{tabular}{|c|c|c|c|c|c|c|c|c|}
\hline & \multicolumn{2}{|c|}{$T=0$} & \multicolumn{2}{|c|}{$T=1$} & \multicolumn{2}{|c|}{$T=2$} & \multicolumn{2}{|c|}{$T=3$} \\
\hline \multicolumn{9}{|l|}{ Dependent variable: Labour earnings } \\
\hline \\
\hline Prize amount $/ 10$ if male & -0.586 & $\begin{array}{l}{[0.324]^{*}} \\
(0.136)\end{array}$ & 0.196 & $\begin{array}{l}{[0.546]} \\
(0.662)\end{array}$ & -0.117 & $\begin{array}{l}{[0.455]} \\
(0.812)\end{array}$ & -0.822 & $\begin{array}{l}{[0.432]^{*}} \\
(0.104)\end{array}$ \\
\hline Prize amount $/ 10$ if female & -0.633 & $\begin{array}{l}{[0.520]} \\
(0.330)\end{array}$ & -1.155 & $\begin{array}{l}{[0.629]^{*}} \\
(0.232)\end{array}$ & 0.307 & $\begin{array}{l}{[0.989]} \\
(0.624)\end{array}$ & 0.995 & $\begin{array}{l}{[0.128]} \\
(0.210)\end{array}$ \\
\hline \multicolumn{9}{|l|}{$b$. By age } \\
\hline Prize amount/10 if younger than 50 & -0.239 & $\begin{array}{l}{[0.357]} \\
(0.602)\end{array}$ & 0.110 & $\begin{array}{l}{[0.546]} \\
(0.826)\end{array}$ & 0.164 & $\begin{array}{l}{[0.550]} \\
(0.722)\end{array}$ & -0.475 & $\begin{array}{l}{[0.611]} \\
(0.402)\end{array}$ \\
\hline Prize amount/10 if older than 50 & -1.055 & $\begin{array}{l}{[0.445]^{* *}} \\
(0.054)^{*}\end{array}$ & -0.272 & $\begin{array}{l}{[0.758]} \\
(0.782)\end{array}$ & -0.305 & $\begin{array}{l}{[0.631]} \\
(0.678)\end{array}$ & -0.598 & $\begin{array}{l}{[0.621]} \\
(0.412)\end{array}$ \\
\hline \multicolumn{9}{|l|}{ c. By household status } \\
\hline Prize amount/10 if living in a couple & -0.618 & $\begin{array}{l}{[0.312]^{* *}} \\
(0.096)^{*}\end{array}$ & 0.103 & $\begin{array}{l}{[0.541]} \\
(0.842)\end{array}$ & 0.090 & $\begin{array}{l}{[0.501]} \\
(0.808)\end{array}$ & -0.507 & $\begin{array}{l}{[0.468]} \\
(0.318)\end{array}$ \\
\hline Prize amount $/ 10$ if single & -0.519 & $\begin{array}{l}{[0.597]} \\
(0.518)\end{array}$ & -0.496 & $\begin{array}{l}{[0.581]} \\
(0.572)\end{array}$ & -0.468 & $\begin{array}{l}{[0.517]} \\
(0.594)\end{array}$ & -0.126 & $\begin{array}{l}{[0.862]} \\
(0.948)\end{array}$ \\
\hline \multicolumn{9}{|l|}{$d$. By earnings } \\
\hline Prize amount $/ 10$ if earnings $<$ median & -0.195 & $\begin{array}{l}{[0.187]} \\
(0.358)\end{array}$ & -0.056 & $\begin{array}{l}{[0.213]} \\
(0.828)\end{array}$ & -0.182 & $\begin{array}{l}{[0.228]} \\
(0.546)\end{array}$ & -0.187 & $\begin{array}{l}{[0.304]} \\
(0.598)\end{array}$ \\
\hline Prize amount $/ 10$ if earnings $>$ median & -0.713 & $\begin{array}{l}{[0.338]^{* *}} \\
(0.096)^{*}\end{array}$ & 0.271 & $\begin{array}{l}{[0.702]} \\
(0.660)\end{array}$ & -0.051 & $\begin{array}{l}{[0.581]^{*}} \\
(0.974)\end{array}$ & -0.483 & $\begin{array}{l}{[0.563]} \\
(0.456)\end{array}$ \\
\hline \multicolumn{9}{|l|}{ e. By parental status } \\
\hline Prize amount $/ 10$ if no children & -0.872 & $\begin{array}{l}{[0.363]^{* *}} \\
(0.060)^{*}\end{array}$ & -0.877 & $\begin{array}{l}{[0.503]^{*}} \\
(0.252)\end{array}$ & -0.385 & $\begin{array}{l}{[0.445]} \\
(0.500)\end{array}$ & -0.897 & $\begin{array}{l}{[0.386]} \\
(0.104)\end{array}$ \\
\hline Prize amount/10 if presence of children & -0.368 & $\begin{array}{l}{[0.438]} \\
(0.482) \\
\end{array}$ & 0.560 & $\begin{array}{l}{[0.773]} \\
(0.358) \\
\end{array}$ & 0.062 & $\begin{array}{l}{[0.685]} \\
(0.864) \\
\end{array}$ & -0.397 & $\begin{array}{l}{[0.775]} \\
(0.562) \\
\end{array}$ \\
\hline \multicolumn{9}{|l|}{ Dependent variable: Employment status } \\
\hline \multicolumn{9}{|l|}{ a. By gender } \\
\hline Prize amount $/ 1,000,000$ if male & & & 0.146 & $\begin{array}{l}{[0.237]} \\
(0.688)\end{array}$ & 0.185 & $\begin{array}{l}{[0.295]} \\
(0.710)\end{array}$ & -0.515 & $\begin{array}{l}{[0.558]} \\
(0.272)\end{array}$ \\
\hline Prize amount $/ 1,000,000$ if female & & & 0.482 & $\begin{array}{l}{[0.335]} \\
(0.776)\end{array}$ & 1.116 & $\begin{array}{l}{[0.462]^{* *}} \\
(0.184)\end{array}$ & 1.580 & $\begin{array}{l}{[0.663]^{* * *}} \\
(0.148)\end{array}$ \\
\hline \multicolumn{9}{|l|}{$b$. By age } \\
\hline Prize amount $/ 1,000,000$ if younger than 50 & & & 0.246 & $\begin{array}{l}{[0.280]} \\
(0.494)\end{array}$ & 0.360 & $\begin{array}{l}{[0.278]} \\
(0.358)\end{array}$ & -0.424 & $\begin{array}{l}{[0.577]} \\
(0.340)\end{array}$ \\
\hline Prize amount $/ 1,000,000$ if older than 50 & & & 0.182 & $\begin{array}{l}{[0.272]} \\
(0.770)\end{array}$ & 0.288 & $\begin{array}{l}{[0.508]} \\
(0.756)\end{array}$ & -0.112 & $\begin{array}{l}{[0.788]} \\
(0.894)\end{array}$ \\
\hline \multicolumn{9}{|l|}{ c. By household status } \\
\hline Prize amount $/ 1,000,000$ if living in a couple & & & 0.101 & $\begin{array}{l}{[0.215]} \\
(0.912)\end{array}$ & 0.297 & $\begin{array}{l}{[0.311]} \\
(0.482)\end{array}$ & -0.270 & $\begin{array}{l}{[0.543]} \\
(0.548)\end{array}$ \\
\hline Prize amount $/ 1,000,000$ if single & & & 0.630 & $\begin{array}{l}{[0.499]} \\
(0.428)\end{array}$ & 0.542 & $\begin{array}{l}{[0.347]} \\
(0.556)\end{array}$ & 0.152 & $\begin{array}{l}{[0.470]} \\
(0.972)\end{array}$ \\
\hline \multicolumn{9}{|l|}{$d$. By earnings } \\
\hline Prize amount $/ 1,000,000$ if earnings $<$ median & & & 0.396 & $\begin{array}{l}{[0.379]} \\
(0.576)\end{array}$ & 0.997 & $\begin{array}{l}{[0.450]^{* *}} \\
(0.100)^{*}\end{array}$ & 0.225 & $\begin{array}{l}{[0.864]} \\
(0.828)\end{array}$ \\
\hline Prize amount/1,000,000 if earnings $>$ median & & & 0.106 & $\begin{array}{l}{[0.184]} \\
(0.806)\end{array}$ & -0.751 & $\begin{array}{l}{[0.286]} \\
(0.826)\end{array}$ & -0.442 & $\begin{array}{l}{[0.500]} \\
(0.338)\end{array}$ \\
\hline \multicolumn{9}{|l|}{ e. By parental status } \\
\hline Prize amount $/ 1,000,000$ if no children & & & 0.222 & $\begin{array}{l}{[0.357]} \\
(0.796)\end{array}$ & 0.291 & $\begin{array}{l}{[0.370]} \\
(0.672)\end{array}$ & -0.121 & $\begin{array}{l}{[0.629]} \\
(0.818)\end{array}$ \\
\hline Prize amount $/ 1,000,000$ if presence of children & & & 0.182 & $\begin{array}{l}{[0.168]} \\
(0.670)\end{array}$ & 0.429 & $\begin{array}{l}{[0.363]} \\
(0.362)\end{array}$ & -0.328 & $\begin{array}{l}{[0.681]} \\
(0.516)\end{array}$ \\
\hline Number of observations & & & & & & 492 & & 78 \\
\hline
\end{tabular}


Table A.8: Heterogeneity of the effect of household lottery prizes on household earnings (including $T>0$ )

\begin{tabular}{|c|c|c|c|c|c|c|c|c|}
\hline & \multicolumn{2}{|c|}{$T=0$} & \multicolumn{2}{|c|}{$T=1$} & \multicolumn{2}{|c|}{$T=2$} & \multicolumn{2}{|c|}{$T=3$} \\
\hline \multicolumn{9}{|l|}{ Dependent variable: Labour earnings } \\
\hline \multicolumn{9}{|l|}{$a$. By household status } \\
\hline Prize amount $/ 10$ if in couple & -0.156 & $\begin{array}{l}{[0.080]^{* *}} \\
(0.090)^{*}\end{array}$ & -0.066 & $\begin{array}{l}{[0.100]} \\
(0.664)\end{array}$ & -0.159 & $\begin{array}{l}{[0.119]} \\
(0.312)\end{array}$ & -0.067 & $\begin{array}{l}{[0.109]} \\
(0.836)\end{array}$ \\
\hline Prize amount $/ 10$ if single & -0.037 & $\begin{array}{l}{[0.076]} \\
(0.770)\end{array}$ & -0.042 & $\begin{array}{l}{[0.082]} \\
(0.912)\end{array}$ & -0.749 & $\begin{array}{l}{[0.292] * * *} \\
(0.402)\end{array}$ & -0.594 & $\begin{array}{l}{[0.376]} \\
(0.650)\end{array}$ \\
\hline \multicolumn{9}{|l|}{$b$. By earnings } \\
\hline Prize amount $/ 10$ if earnings $<$ median & -0.064 & $\begin{array}{l}{[0.049]} \\
(0.166)\end{array}$ & -0.080 & $\begin{array}{l}{[0.023]^{* * * *}} \\
(0.244)\end{array}$ & -0.207 & $\begin{array}{l}{[0.095]^{* *}} \\
(0.022)^{* *}\end{array}$ & -0.153 & $\begin{array}{l}{[0.047] * * *} \\
(0.378)\end{array}$ \\
\hline Prize amount $/ 10$ if earnings $>$ median & -0.137 & $\begin{array}{l}{[0.064]^{* *}} \\
(0.258)\end{array}$ & 0.086 & $\begin{array}{l}{[0.135]} \\
(0.688)\end{array}$ & -0.056 & $\begin{array}{l}{[0.085]} \\
(0.854)\end{array}$ & -0.198 & $\begin{array}{l}{[0.116]^{*}} \\
(0.562)\end{array}$ \\
\hline \multicolumn{9}{|l|}{ c. By parental status } \\
\hline Prize amount $/ 10$ if no children & -0.047 & $\begin{array}{l}{[0.108]} \\
(0.672)\end{array}$ & 0.075 & $\begin{array}{l}{[0.089]} \\
(0.682)\end{array}$ & 0.034 & $\begin{array}{l}{[0.077]} \\
(0.738)\end{array}$ & -0.108 & $\begin{array}{l}{[0.101]} \\
(0.768)\end{array}$ \\
\hline Prize amount/10 if children & -0.191 & $\begin{array}{l}{[0.065]^{* * *}} \\
(0.068)^{*}\end{array}$ & -0.159 & $\begin{array}{l}{[0.076]^{* *}} \\
(0.304)\end{array}$ & -0.328 & $\begin{array}{l}{[0.100]^{* * * *}} \\
(0.030)^{* *}\end{array}$ & -0.073 & $\begin{array}{l}{[0.131]} \\
(0.846)\end{array}$ \\
\hline Number of observations & \multicolumn{2}{|c|}{35,603} & \multicolumn{2}{|c|}{27,246} & \multicolumn{2}{|c|}{17,417} & \multicolumn{2}{|c|}{8,736} \\
\hline
\end{tabular}

Table A.9: Heterogeneity of the effect of household lottery prizes on household earnings excluding prizes above $€ 500,000$ (including $T>0$ )

\begin{tabular}{|c|c|c|c|c|c|c|c|c|}
\hline \multirow{2}{*}{ Dependent variable: Labour earnings } & \multicolumn{2}{|c|}{$T=0$} & \multicolumn{2}{|c|}{$T=1$} & \multicolumn{2}{|c|}{$T=2$} & \multicolumn{2}{|c|}{$T=3$} \\
\hline & & & & & & & & \\
\hline Prize amount $/ 10$ if in couple & 0.225 & $\begin{array}{l}{[0.323]} \\
(0.686)\end{array}$ & 0.810 & $\begin{array}{l}{[0.522]} \\
(0.298)\end{array}$ & 0.524 & $\begin{array}{l}0.468] \\
(0.642)\end{array}$ & 0.122 & $\begin{array}{l}{[0.494]} \\
(0.868)\end{array}$ \\
\hline Prize amount $/ 10$ if single & -0.132 & $\begin{array}{l}{[0.255]} \\
(0.934)\end{array}$ & -0.477 & $\begin{array}{l}{[0.267]} \\
(0.654)\end{array}$ & -0.749 & $\begin{array}{l}{[0.292]^{* * *}} \\
(0.402)\end{array}$ & -0.594 & $\begin{array}{l}{[0.376]} \\
(0.650)\end{array}$ \\
\hline \multicolumn{9}{|l|}{ b. By earnings } \\
\hline Prize amount $/ 10$ if earnings $<$ median & -0.107 & $\begin{array}{l}{[0.229]} \\
(0.734)\end{array}$ & -0.172 & $\begin{array}{l}{[0.224]} \\
(0.650)\end{array}$ & -0.173 & $\begin{array}{l}{[0.278]} \\
(0.690)\end{array}$ & -0.113 & $\begin{array}{l}{[0.276]} \\
(0.848)\end{array}$ \\
\hline Prize amount $/ 10$ if earnings $>$ median & -0.146 & $\begin{array}{l}{[0.307]} \\
(0.794)\end{array}$ & 0.693 & $\begin{array}{l}{[0.632]} \\
(0.450)\end{array}$ & 0.215 & $\begin{array}{l}{[0.524]} \\
(0.762)\end{array}$ & -0.452 & $\begin{array}{l}{[0.545]} \\
(0.638)\end{array}$ \\
\hline \multicolumn{9}{|l|}{ c. By parental status } \\
\hline Prize amount $/ 10$ if no children & 0.014 & $\begin{array}{l}{[0.323]} \\
(0.942)\end{array}$ & -0.018 & $\begin{array}{l}{[0.446]} \\
(0.954)\end{array}$ & 0.078 & $\begin{array}{l}{[0.494]} \\
(0.900)\end{array}$ & -0.351 & $\begin{array}{l}{[0.467]} \\
(0.688)\end{array}$ \\
\hline Prize amount/10 if children & 0.266 & $\begin{array}{l}{[0.415]} \\
(0.708)\end{array}$ & 0.962 & $\begin{array}{l}{[0.695]} \\
(0.278)\end{array}$ & 0.302 & $\begin{array}{l}{[0.552]} \\
(0.658)\end{array}$ & 0.267 & $\begin{array}{l}{[0.675]} \\
(0.762)\end{array}$ \\
\hline Number of observations & \multicolumn{2}{|c|}{35,589} & \multicolumn{2}{|c|}{27,239} & \multicolumn{2}{|c|}{17,412} & \multicolumn{2}{|c|}{8,734} \\
\hline
\end{tabular}




\section{G Family spillovers}

Table A.10: Family spillover effects

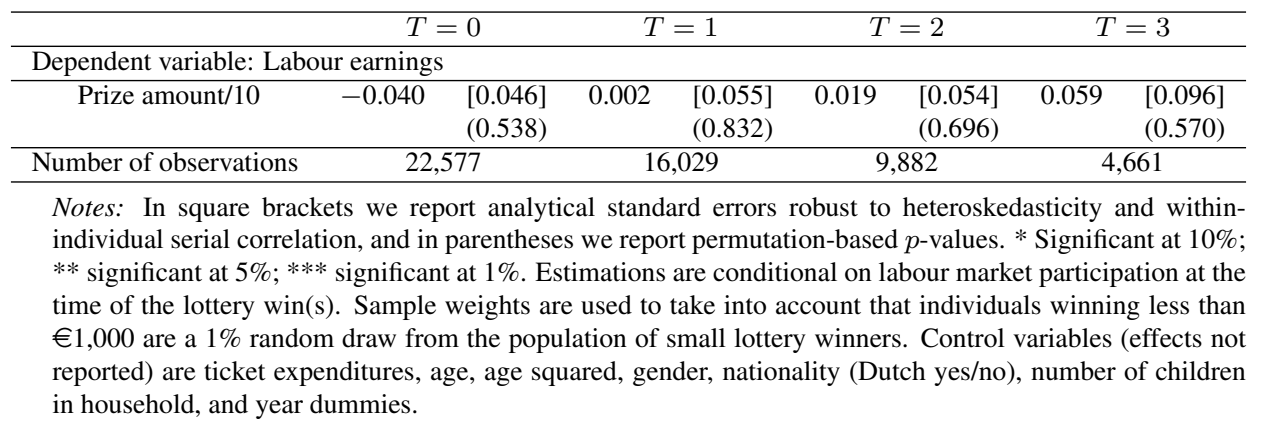

